\title{
Ireland: Submerged Prehistoric Sites and Landscapes
}

\author{
Kieran Westley and Peter Woodman
}

\section{Abstract}

Evidence of Ireland's drowned landscapes and settlements presently comprises 50 sites spread across the entire island. These comprise mainly intertidal find spots or small collections of flint artefacts. A handful of fully subtidal sites are known, generally from nearshore regions and consisting, with one exception, of isolated single finds. Evidence of organic remains is also sparse, with the exception of Mesolithic and Neolithic wooden fish traps buried in estuarine sediments under Dublin. The relatively small number of sites is probably due to lack of research as much as taphonomic issues, and thus the current evidence hints at the potential archaeological record which may be found underwater. Such evidence could contribute to knowledge of the coastal adaptations and seafaring abilities of Ireland's earliest inhabitants. Nonetheless, taphonomic considerations, specifically relating to Ireland's history of glaciation, sea-level change and also modern oceanographic conditions likely limit the preservation of submerged landscapes and their associated

K. Westley $(\bowtie)$

School of Geography and Environmental Sciences, Ulster University, Coleraine, Northern Ireland, UK e-mail: kl.westley@ulster.ac.uk

P. Woodman (Deceased)

Department of Archaeology, University College

Cork, Cork City, Republic of Ireland archaeology. Realistically, the Irish shelf is likely characterised by pockets of preservation, which makes detection and study of submerged landscapes difficult but not impossible. A range of potential routes of investigation are identifiable, including site-scale archaeological survey, landscape-scale seabed mapping, archival research and community engagement.

\section{Keywords}

Submerged prehistoric sites $\cdot$ Intertidal archaeology $\cdot$ Holocene sea-level rise . Submerged forests $\cdot$ Fish traps $\cdot$ Maritime adaptation

\subsection{Introduction}

The island of Ireland lies to the west of Great Britain, separated from it by the Irish Sea. At present, it is politically divided between Northern Ireland (part of the United Kingdom) and the Republic of Ireland and, as such, its historic environment is recorded and managed under two separate jurisdictions. However, in this chapter, the submerged archaeological record of the entire island will be considered as a whole, for the simple reason that this political boundary did not exist in prehistory. The aim of this chapter is to review the extant evidence for submerged archae- 
ological landscapes around Ireland, discuss any patterns visible in the data, identify the potential contribution of these landscapes to Irish archaeology and, finally, comment on potential avenues of future investigation. The timeframe under consideration focuses on the Irish Mesolithic and the early Neolithic (c. 10,500-5500 cal BP) because, as demonstrated below, most submerged landscape evidence from Ireland likely dates to this interval.

Before proceeding to the evidence, a brief review of the archaeological, sea-level and palaeogeographic background is needed. This will not only set the scene for readers unfamiliar with Irish prehistory but also identify issues in the extant evidence base which, as will become apparent later, are directly relevant to the study of submerged prehistoric landscapes. More detailed recent overviews of the Irish Mesolithic can be found in Woodman (2015) and Warren (2017), while a similarly recent overview covering submerged Quaternary palaeolandscapes and taphonomic issues can be found in Westley and Edwards (2017).

\subsection{Archaeological Background}

Ireland's prehistoric record bears some similarities with neighbouring Britain but also some major differences. One key distinction is the lack of Palaeolithic evidence compared to Britain, which was occupied as far back as c. 0.780.99 million years ago and is evidenced by wellpreserved in situ sites as well as extensive secondary context assemblages (Pettitt and White 2012; Bailey et al., Chap. 10, this volume). The Irish evidence so far consists of four isolated lithic finds (two handaxes and two flakes) of Lower to Middle Palaeolithic appearance. However, the provenance of the handaxes is uncertain while the flakes are derived from reworked contexts (Woodman 2015; Warren 2017). Most recently, a cut-marked bear patella from Alice and Gwendoline Cave (Co. Clare) was radiocarbon dated to $12,810-12,590 \mathrm{cal} \mathrm{BP}$ along with a second cut-marked bear vertebra dated to 11,080-10,400 cal BP (Dowd and
Carden 2016). The former presents the strongest available evidence for, at the very least, a human incursion into Ireland during the final Palaeolithic.

Even if the possibility of Palaeolithic occupation, or at least pioneer incursion(s), cannot be ruled out, the earliest incontrovertible evidence of full-scale human colonisation and settlement comes during the Mesolithic. This is the site of Mount Sandel, an occupation site situated close to the north coast and dated to c. $9800 \mathrm{cal} \mathrm{BP}$ (Bayliss and Woodman 2009; Woodman 2015). By comparison, Britain has Late Glacial huntergatherers present throughout the GI-1 interstadial (c. 14,600-12,900 cal BP; Pettitt and White 2012), and even after near-total depopulation in the first half of the cold GS-1/Younger Dryas stadial (c. 12,900-11,500 cal BP), humans had returned from c. 12,000 cal $\mathrm{BP}$ onwards in the form of Epi-Ahrensburgian hunters (Pettitt and White 2012; Warren 2017).

The reasons for the missing Irish Palaeolithic remain unclear. For the pre-Last Glacial Maximum (LGM), this could be partly explained by the scouring effect of multiple glaciations and the fact that Ireland's location may have been too peripheral for anything other than sporadic pioneer expeditions. However, for the Late Glacial and Mesolithic, there is still a delayed occupation relative to Britain which cannot be explained by purely taphonomic factors and could relate to social and ecological factors, not least the 'impoverished' nature of the Irish fauna (see Woodman 2015 and Warren 2017 for a fuller account of these issues).

Ireland's earliest occupants likely arrived from Britain, bringing with them similar toolkits and strategies. In Britain, the early Mesolithic (c. 11,500 to $10-10,500 \mathrm{cal} \mathrm{BP}$ ) is typified by forms such as obliquely blunted points, broad blade microliths and slender uniserial bone/antler barbed points. By c. 10,500-10,000 cal BP, these assemblages gave way to different forms, characteristically narrow blade or geometric microliths and flat, squat barbed bone/antler points (the later Mesolithic; Tolan-Smith 2009; Warren 2017). The first thousand years of the Irish Mesolithic (c. 9800-8800 cal BP) show some similarities with British later Mesolithic assemblages (as 
expected given the colonists' likely origins), most evidently in the form of geometric microliths, but also differences, such as distinctive small core and flake axes not found in contemporary British sites. Once established in Ireland, the trajectory of the Irish Mesolithic departs further. From c. 8800 to $8600 \mathrm{cal}$ BP, tool assemblages become dominated by a 'macrolithic' industry of large blades, flakes and distinctive butt-trimmed forms which have no British counterpart, except on the Isle of Man. Bone artefacts also differ as the barbed points of the British Mesolithic are not present in Ireland; instead, slender points without barbs were used (Woodman 2012, 2015). Effectively, this means that the British Late Mesolithic can be regarded as equivalent to the Irish Earlier Mesolithic, while the Irish Later Mesolithic has no parallels in mainland Britain (Warren 2015a). For the rest of this chapter, unless otherwise stated, the terms 'Earlier' and 'Later Mesolithic' will be used by reference to the Irish typochronology.

As elsewhere in north-west Europe, the Mesolithic was characterised by mobile populations hunting and gathering terrestrial, lacustrine, riverine and, to some extent, marine resources (note, however, questions regarding the level of coastal adaptation which will be discussed later). This way of life was then replaced by the Neolithic with its new agricultural practices, burial traditions, built structures and material culture. Dating of the key transition interval has been refined to 5700-5570 cal BP and comprised a 40-100 year 'boom' in Neolithic settlement evidenced by the rapid spread of distinct rectangular houses, appearance of domestic cereals (wheat and barley) and adoption of longterm fixed plot agriculture (Whitehouse et al. 2014). However, there are hints of earlier Neolithic-like activity in the form of burials and also domestic cattle bones from the final Mesolithic site of Ferriter's Cove south-west Ireland) dated to 6400-6220 cal BP. Whether this is indicative of an earlier colonisation event or contact between indigenous Mesolithic populations and incoming Neolithic ones is still unclear (Garrow and Sturt 2011; Whitehouse et al. 2014; Warren 2017).

\subsection{Sea-Level and Palaeogeographic Change}

Like much of north-west Europe, Late Pleistocene and Holocene relative sea-level (RSL) change around Ireland was driven by the interplay between global glacio-eustatic ocean volume change and local- to regional-scale isostatic response to ice loading during the LGM and unloading thereafter. The resulting impact on RSL change was particularly complex as Ireland is located in a transitional zone between uplifting formerly glaciated and collapsing forebulge areas (Edwards and Craven 2017; Westley and Edwards 2017).

At its maximum extent (c. 27,000-23,000 cal BP), ice entirely covered Ireland and its continental shelf as far west and south as the Atlantic shelf break and Celtic Sea shelf edge, respectively. Thickness, duration and timing of maximum extent of ice cover all varied spatially (Clark et al. 2012; Ballantyne and O Cofaigh 2017). Where ice was thickest and longest lasting, isostatic depression and subsequent postglacial rebound were greatest. This is exemplified by Ireland's north-east corner and was further enhanced by proximity to the regional centre of ice loading in Fenno-Scandinavia. Moving south and south-west across the island, isostatic rebound diminished with distance from the centre of ice loading (Westley and Edwards 2017).

This resulted in RSL histories which vary spatially and are often non-monotonic, i.e., characterised by variations in the rate of RSL change and, in some places, complete oscillations. Reconstructing these patterns has been hindered by an uneven distribution of accurate Sea-Level Index Points (SLIP), particularly for the Late Glacial and intervals during which RSL fell below present (Westley and Edwards 2017). Consequently, emphasis has been placed on modelling isostatic rebound and its effect on RSL using Glacio-Isostatic Adjustment (GIA) models constrained by the available field evidence. There are, however, still uncertainties for the earliest Holocene and Late Glacial to be addressed, and different models also deviate from one another- 
generally in terms of magnitude rather than pattern-depending on differences in the input ice loading histories (Edwards and Craven 2017). There is also ongoing debate regarding the reconciliation of field data with model results, particularly for the Late Glacial in north-east Ireland (see McCabe et al. 2007; McCabe 2008; Edwards et al. 2008). Consequently, RSL reconstructions for Ireland are still a work-in-progress, though the general pattern of change-certainly for the Holocene-is well established. One clear feature arising from all models and field evidence is that an RSL lowstand occurred across the entire Irish shelf during the Late Glacial and Early Holocene, i.e., coincident with the earliest occupation and colonisation of Ireland. However, its timing and magnitude varied around the island due to differential isostatic rebound (Fig. 11.1).
In the extreme south and south-west, RSL rose from a lowstand of c. -50 to $-90 \mathrm{~m}$ (precise values vary depending on the GIA model used; Edwards and Craven 2017) and reached modern sea level in the Late Holocene (Brooks et al. 2008; Bradley et al. 2011; Kuchar et al. 2012). RSL rise was not constant, with models indicating variations in the rate of RSL rise and sometimes oscillations, though of insufficient magnitude to bring RSL above present level. The lack of evidence for RSL above present reflects reduced ice loading and hence the greater influence of glacio-eustasy.

Moving north and east, the influence of isostasy increases. Upon deglaciation, the resulting impact on sea level was a generalised pattern of 'rise-fall-rise' (Edwards and Craven 2017). This consisted of initially higher-than-present RSL,

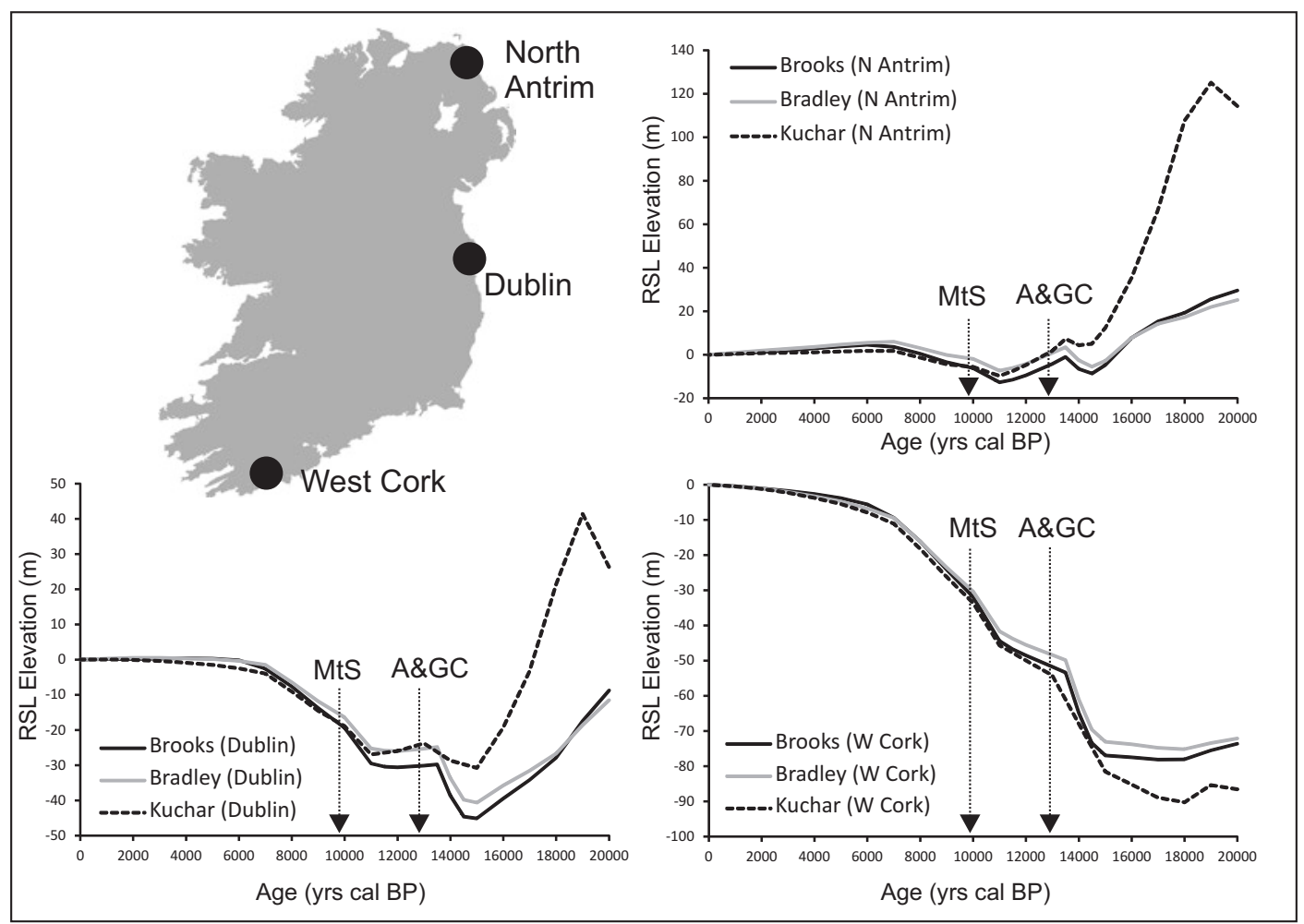

Fig. 11.1 RSL curves derived from the Brooks et al. (2008), Bradley et al. (2011) and Kuchar et al. (2012: min ice model) GIA models. Selected curves highlight the variation between the centre of ice loading in the north-east (North Antrim) and reduced ice loading in the south-west (West Cork). The RSL curve from Dublin presents an intermediate example between the two extremes. Note that despite the range of inter-model variation, they all agree on an RSL lowstand around the time of Ireland's earliest occupation, indicated by dates for Mount Sandel (MtS) and the Alice and Gwendoline Cave bear patella (A\&GC). Data courtesy of Robin Edwards and Joseph Kuchar 
followed by RSL fall to a lowstand below present, and finally another RSL rise to the present. Again, the magnitude and timings of the various lowstands and highstands are location- and model-dependent. In the extreme north-east, where isostatic recovery was greatest, the final RSL rise resulted in an additional minor midHolocene highstand of a few metres above present which, due to continued rebound, gave way to RSL falling to its present level. Zones in between the extreme north-east and south-west saw variations on these patterns. In general, the main trends were a reduction in initial Late Glacial highstand elevation, an increasingly long and deep lowstand and absence of the mid-Holocene highstand as one moves south and west (Edwards and Craven 2017; Westley and Edwards 2017).

Palaeogeographic reconstructions have been produced by correcting Digital Elevation Models (DEMs) of the land and seabed with GIAmodelled histories of RSL change (Fig. 11.2; Edwards and Brooks 2008; Brooks et al. 2011; Sturt et al. 2013). Again, there are minor differences between reconstructions depending on the GIA model used and the resolution of the input bathymetric/topographic surface (Edwards and Craven 2017). However, all recent reconstructions agree that Ireland was cut off from mainland Britain from a relatively early date (c. 16,000 cal BP [Edwards and Brooks 2008], 15,000 cal BP [Brooks et al. 2011]) and was an island by the time of its earliest settlement. Though the reconstructions are coarse and do not take into account bathymetric variation resulting from sedimentation or erosion, they also suggest that most of the larger bays and inlets were not created till after c. 12,000-13,000 cal BP, and most appear to have formed between c. 10,000 and 8000 cal BP (Edwards and Brooks 2008; Brooks et al. 2011; Sturt et al. 2013).

\subsection{Overview of Submerged Archaeological Sites}

A database of submerged archaeological sites around Ireland, comprising all known instances of subtidal or intertidal assemblages with prehis- toric evidence, has been compiled for the SPLASHCOS project (Bailey and Sakellariou 2012). Sites were identified from the published and grey literature, existing gazetteers or Historic Environment Records and the authors' personal knowledge. There are currently 50 sites recorded in the database, of which 11 are fully subtidal, 38 are intertidal and 1 is deeply buried below sea level under reclaimed land (Fig. 11.3). Given the cut-off date of 5500 cal BP specified for the initial database compilation, the recorded sites are mainly Mesolithic, with a handful of early Neolithic entries. Where possible, chronology has been based on radiocarbon dates or, if lacking, diagnostic artefacts. Sites without either radiocarbon dates or diagnostic finds (17 in total) are assumed to predate $5500 \mathrm{cal} \mathrm{BP}$ and are conservatively placed in a broad prehistoric period since a Mesolithic/Neolithic attribution is not confirmed but cannot be ruled out. Details of chronological assignation for each site can be found in the database hosted on the SPLASHCOS Viewer (http://www.splashcos-viewer.eu).

The spatial distribution of sites is heavily biased to the north and north-east coasts (35 sites versus 15 for the rest of Ireland). This mirrors the distribution of the terrestrial Irish Mesolithic. Reasons for the dense concentration in the northeast are argued to be a product of a long history of research and extensive lithic evidence resulting from readily available flint sources as much as former occupation preferences (Woodman 2015). Interestingly, this pattern also mirrors the RSL history described above, with the majority of submerged sites located where the lowstand was shallowest and few in the south and west where the lowstand was deepest. The implications of this will be discussed later.

The following subsections will describe in more detail the submerged archaeological record, splitting it according to its current location, i.e., subtidal versus intertidal assemblages. Two other broad categories of evidence not included in the database, but which pertain to submerged landscapes, are also examined. These are intertidal and submerged organic deposits lacking archaeological finds and artefact-bearing raised beach deposits currently situated above present sea level. 
Brooks et al. (2008)
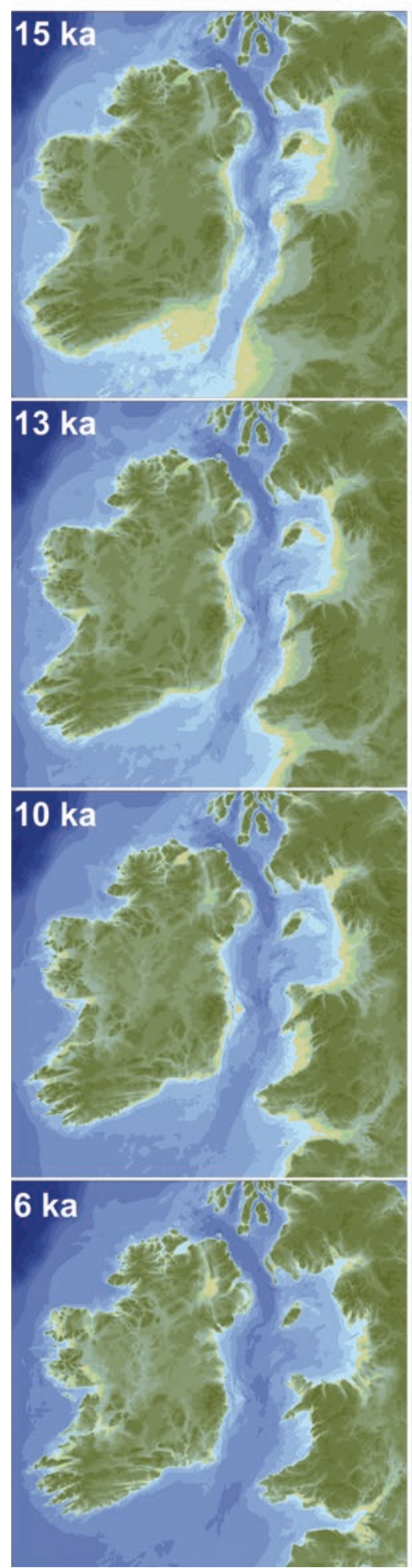

Kuchar et al. (2012)
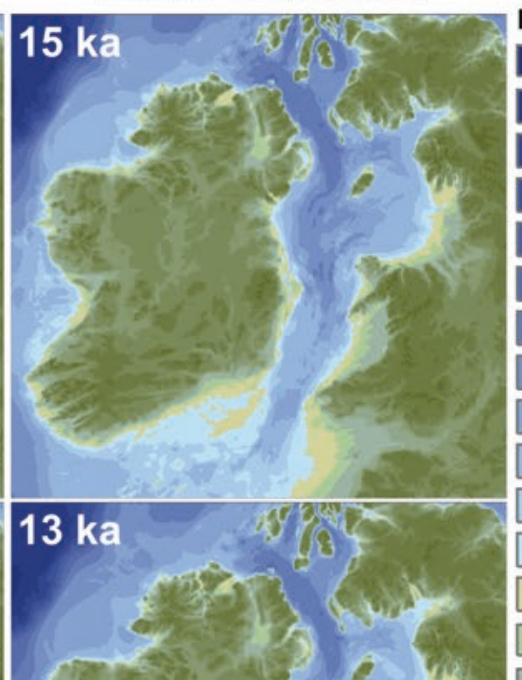

Elevation (m)

$<-2,500$

$-2,500--2,000$

$-2000--1,500$

$-1,500--1,000$

$-1000--500$

$-500--200$

$-200--100$

$-100--60$

$-60--40$

$-40--20$

$-20=-10$

$-10-0$

$0-10$

$10-20$

$20-40$

$40-60$

$60-100$

$100-200$

$200-500$

$500-1,000$

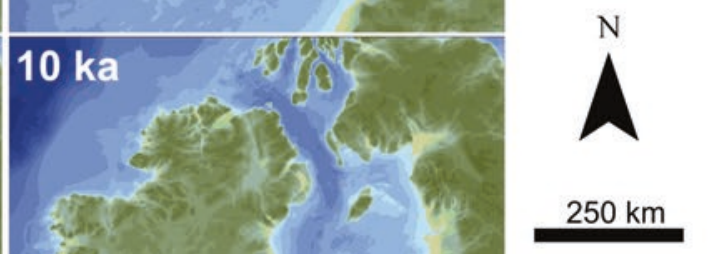

$250 \mathrm{~km}$

Fig. 11.2 Regional-scale palaeogeographic reconstructions based on GIA-modelled RSL histories from Brooks et al. (2008) and Kuchar et al. (2012). See Brooks et al. (2011) and Sturt et al. (2013) for similar reconstructions based on Bradley et al. (2011). Note similarities between reconstructions despite different ice loading inputs. 


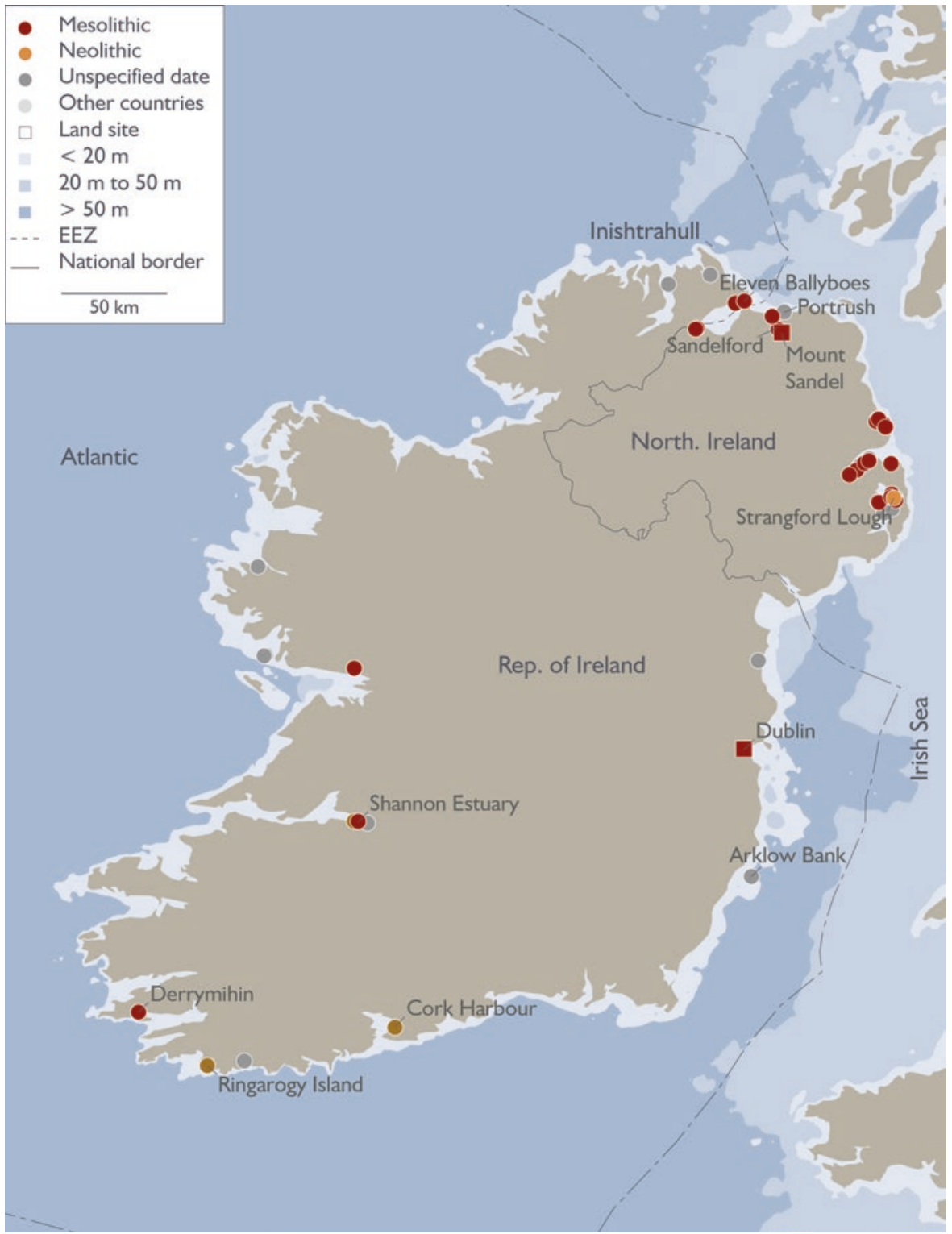

Fig. 11.3 Overview map showing location of all known subtidal and intertidal archaeological sites predating 5500 cal BP from the island of Ireland. Site information from the SPLASHCOS Viewer http://splaschos-viewer.eu. Drawing by Moritz Mennenga

Fig. 11.2 (continued) Timesteps roughly bracket the post-LGM recolonisation of Britain (onset of the Late Glacial interstadial, c. 15,000 cal BP), potential pioneer incursions into Ireland (Alice and Gwendoline Cave bear patella, c. 13,000 cal BP), Mesolithic settlement of Ireland (Mount Sandel, c. 10,000 cal BP) and the end of the Irish Mesolithic (c. 6000 cal BP). Reconstructions should be considered only as first approximations as they are not corrected for palaeotidal changes or bathymetric variations resulting from sediment deposition or erosion. The underlying Digital Elevation Model is the GEBCO (2014) global 30 arc-second grid. RSL data courtesy of Robin Edwards, Tony Brooks and Joseph Kuchar 


\subsubsection{Subtidal Archaeological Finds}

Despite the exposure of land available for settlement around the entire island, Ireland currently has no completely subtidal in situ prehistoric sites. At the time of writing, the subtidal record consists of 11 identified find spots of stray finds or reworked assemblages of lithic material which have been found either by dredging or by divers. Eight of these comprise only isolated stray finds:

1. Two worked flints dredged from the Arklow Bank $(10 \mathrm{~km}$ off the east coast; Campbell 2003).

2. A ground stone point trawled from near Derrymihin/Minane Island on the south-west coast (Fig. 11.4; O'Riordain 1953).

3. A single flint flake dredged from Larne Lough on the north-east coast (Common 1933).

4. A few possible struck flakes from a larger assemblage of natural gravel dredged from the Boyne Estuary on the east coast (Brady and Pollard 2013).

5. A single flake found by a diver off Glandore on the south-west coast.

6. A possible flint core recovered in a lobster pot off Renvyle on the west coast (M. Gibbons pers. comm.)

7. A polished stone axe head found by a diver at $18 \mathrm{~m}$ depth at the base of Muglins Rock,

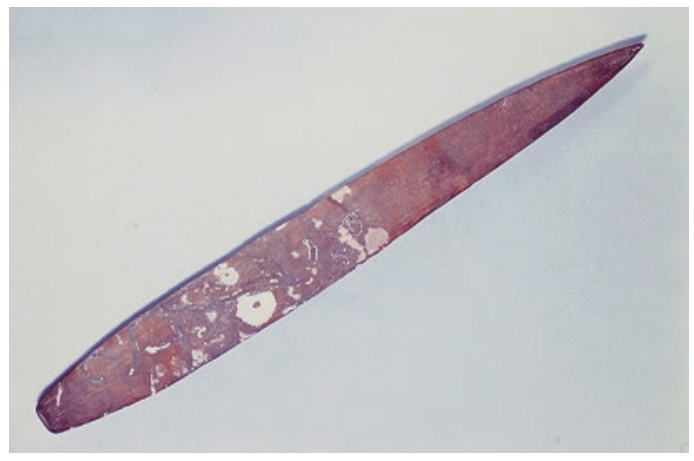

Fig. 11.4 Ground stone point (40 cm long) dredged off Derrymihin, south-west Ireland, possibly a Moynagh point of Later Mesolithic date. The surface discolorations probably result from growth of marine organisms. Photo: National University of Ireland, Galway
Dalkey Sound, on the east coast (Cooney and Mandal 1998).

8. Up to four struck flint flakes recovered from pollution monitoring grab samples in Belfast Lough on the north-east coast ( $\mathrm{R}$. McNeary pers. comm.)

With the exception of the Arklow Bank (c. 10-20 m deep, $10 \mathrm{~km}$ offshore), all the above sites cluster in nearshore waters, particularly in sheltered bays and estuaries. A larger collection of up to 45 lithics including flakes, blades and axes was also recovered by divers from the River Corrib (Driscoll 2006). The reported location is c. $3 \mathrm{~km}$ from the sea, and it is uncertain if this material was directly deposited in the river or submerged by higher river levels caused by RSL rise downstream or changing lake levels in Lough Corrib further upstream. Nevertheless, it is included as an example of material potentially deposited in an estuarine location and later inundated because of RSL rise.

Diagnostic artefacts are lacking from most of the above find spots. The exceptions are the Derrymihin/Minane Island stone point which is classified as a Moynagh Point, a form generally associated with Later Mesolithic assemblages (Woodman 2015), and the River Corrib collection which includes some diagnostic Later Mesolithic items such as butt-trimmed forms and a bar form (Driscoll 2006).

The final subtidal site is Eleven Ballyboes, located on the north coast (Co. Donegal). This is presently the only subtidal prehistoric site in Ireland subject to systematic archaeological investigation (Westley 2015). The location comprises two small (<c. $50 \mathrm{~m}$ wide) bays with sandy pocket beaches. Investigation focused here after large numbers of lithics (c. 1600 to date) were discovered strewn across the shore by a group of amateur collectors (McNaught 1998). Follow-up work confirmed that these were Earlier Mesolithic in age, based on the presence of diagnostic narrow blades, platform cores and distinctive flake axes (Fig. 11.5; Costa et al. 2001). In the westernmost bay, systematic survey and test excavation recovered c. 120 lithics from underwater, including buried items as well as examples lying 


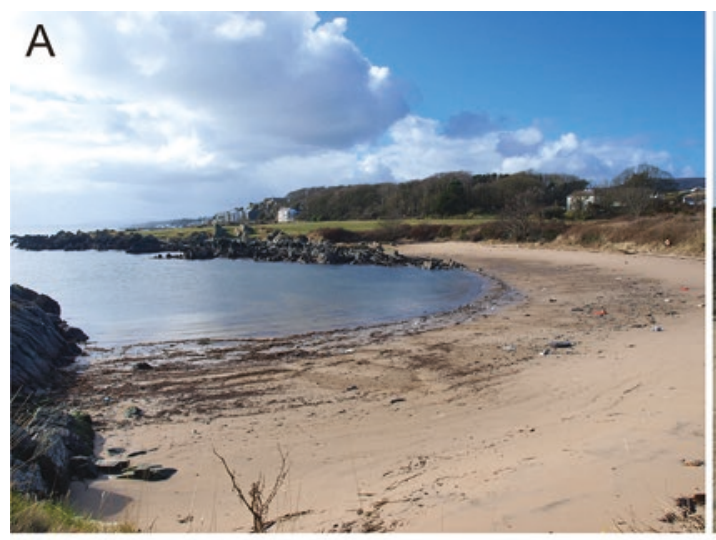

B

\section{C}

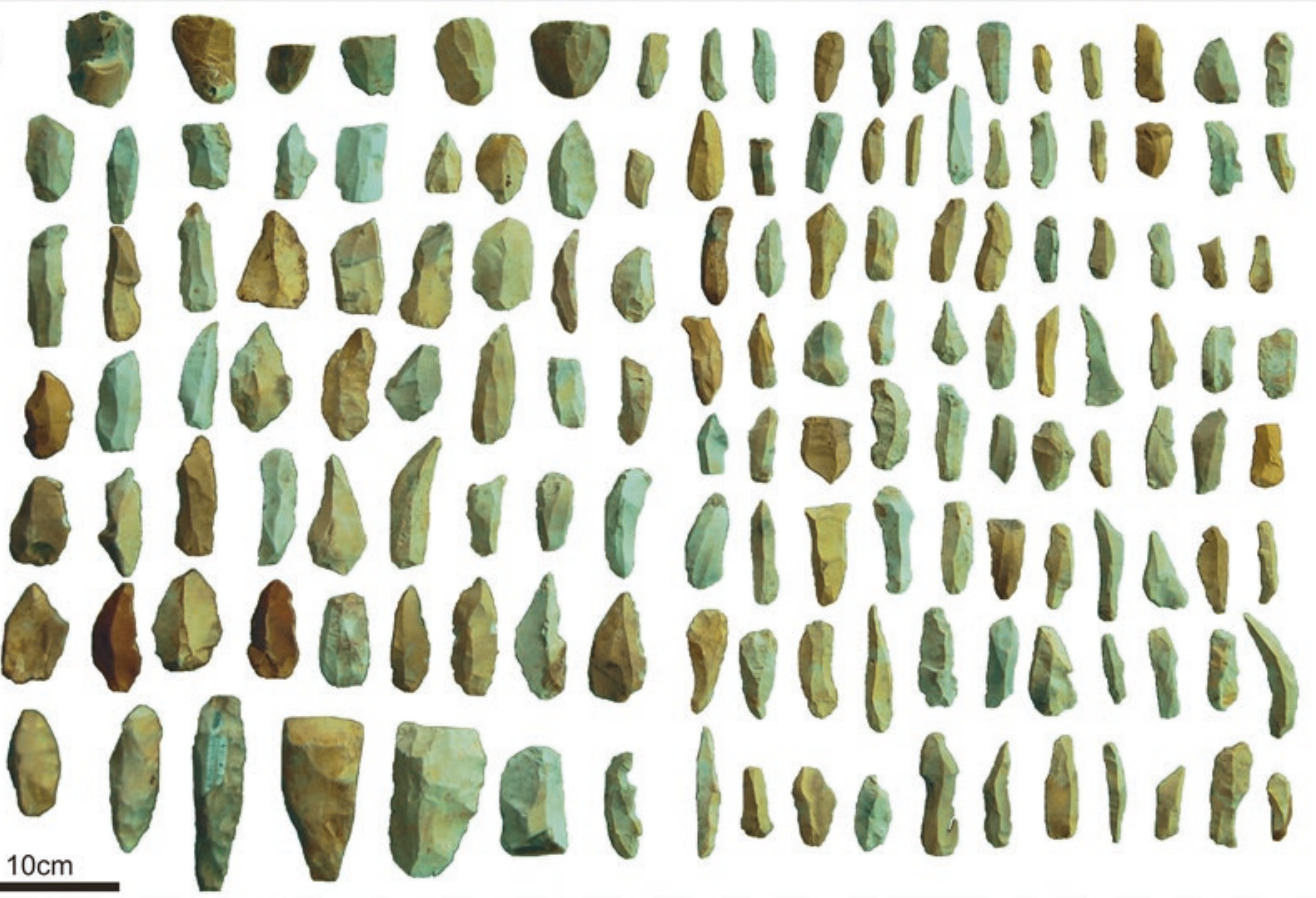

Fig. 11.5 Eleven Ballyboes (Co. Donegal) views across the (a) western and (b) eastern bay and beach. (c) Representative sample of lithic finds from the intertidal zone including blades, flakes, cores and axes. Photos by K. Westley

loose on the seabed (Fig. 11.6). Some are fresh and unpatinated and contrast with their stained and water-rolled counterparts recovered from the beach, thus indicating that the source deposit was located underwater. Excavation identified this source as a gravel deposit located c. $30 \mathrm{~m}$ offshore in c. $2 \mathrm{~m}$ water depth from which artefacts are periodically washed out onto the adjacent beach and seabed. However, it also confirmed that this deposit has already been reworked by wave and tidal processes, and consequently, while the finds can be localised to a relatively small area, they are no longer in situ (Westley 2015).

By contrast, the easternmost bay has only produced three undiagnostic and water-rolled subtidal flints. However, it was found to contain a submerged peat layer at roughly the same depth as the find-bearing gravel in the western bay (c. $<2 \mathrm{~m}$ depth). Organic preservation is excellent, with large chunks of wood, sphagnum moss and hazelnuts preserved in situ (Fig. 11.7). 


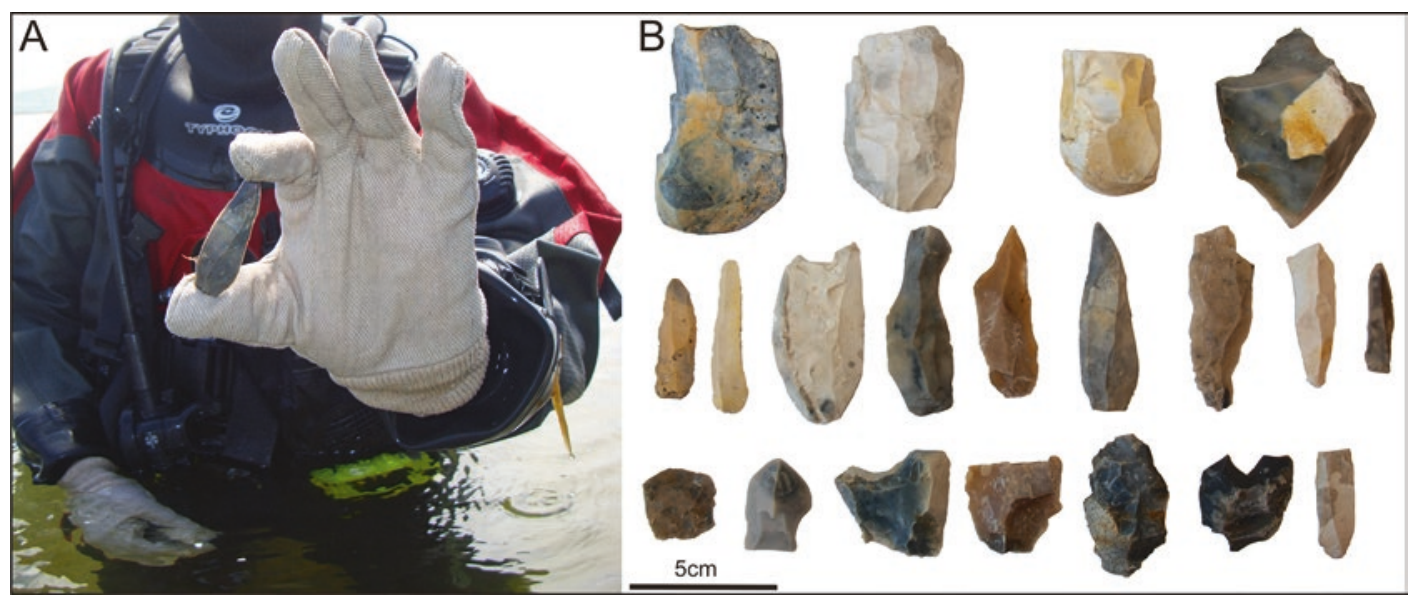

Fig. 11.6 Subtidal Mesolithic flints from Eleven Ballyboes (Co. Donegal). (a) Diver with flint blade recovered from the seabed. (b) Representative sample of lithic finds from below low water. Photos by W. Forsythe, K. Westley

Fig. 11.7 Submerged peat from the eastern bay, Eleven Ballyboes. (a) Seaward edge of the peat lay visibly breaking up into large chunks. (b) Exposed surface of the peat layer showing preserved wood. Photos by K. Westley
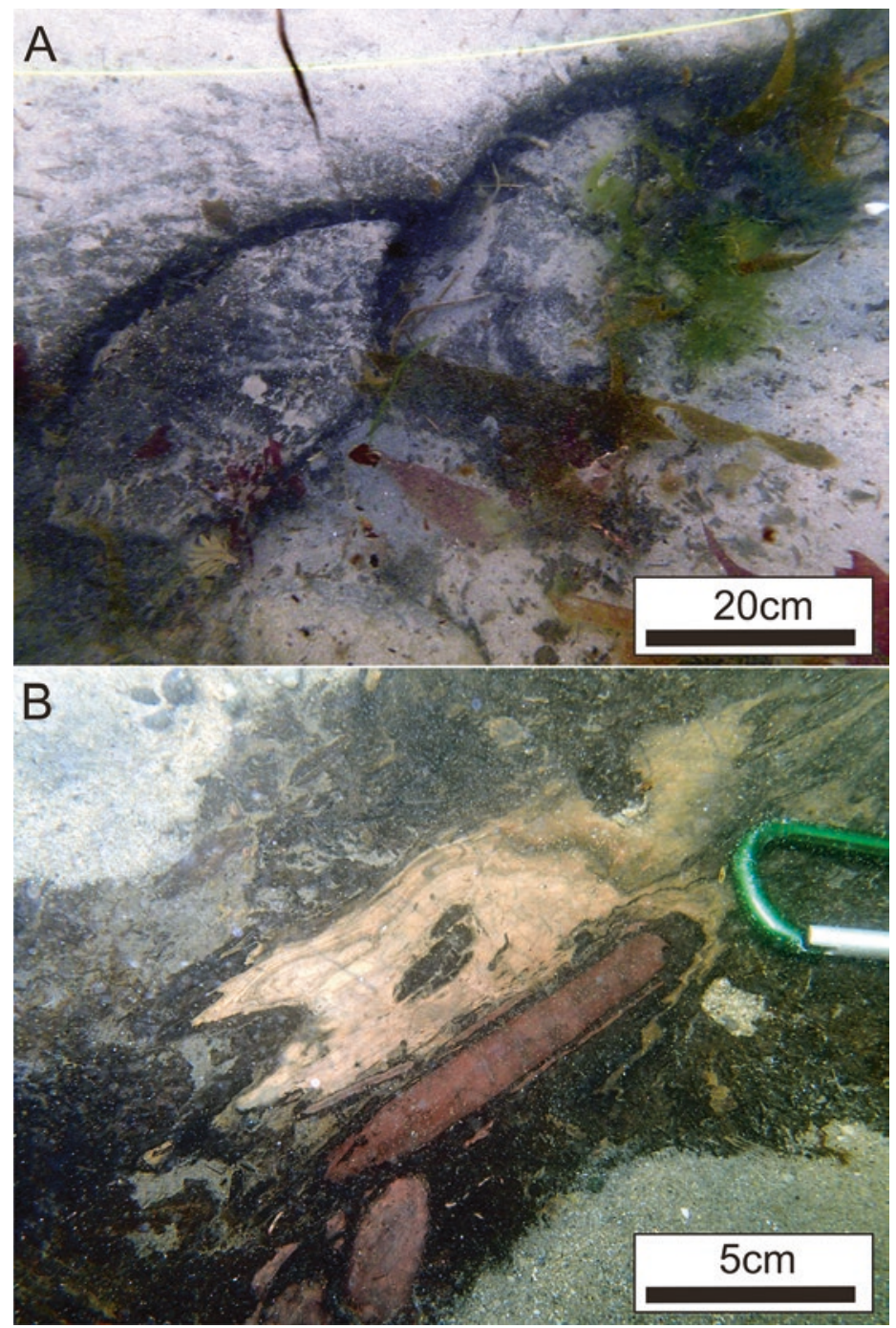
Radiocarbon dates place the peat between $\mathrm{c}$. 9400 and 8700 cal BP which is in accordance with the Earlier Mesolithic attribution of the lithic finds. No archaeological finds were made from the peat, and it is unclear if this relates to a true lack of evidence or just the limited sampling strategy (Westley 2015). In a European context, Eleven Ballyboes is not especially significant, being relatively small and with no in situ finds yet identified. In an Irish context, it has a somewhat greater importance in that it gives an indication of the nature of the archaeological record potentially located offshore and highlights the localised taphonomic processes which characterise large parts of the Irish shelf. In this case, for example, two adjacent bays show very different stratigraphy and preservation conditions.

\subsubsection{Intertidal Archaeological Assemblages}

Thirty-eight intertidal locations, mainly located along the north and north-east coast, have also produced archaeological evidence consisting mainly of flint tools washed up onto the upper part of the intertidal shore. The two largest concentrations are around Strangford and Belfast Loughs, both sea loughs created during the early Holocene and where historically many collectors have been active (Woodman 1978; McErlean et al. 2002).
Good examples from these loughs where material has been found close to low-water mark are Sydenham Station (Belfast Lough) and Big Stone Bay (Strangford Lough). The former consists of a selection of struck flints (of Later Mesolithic appearance) recovered from an eroded intertidal surface in the late nineteenth century (Patterson 1892; Woodman 1978). Though the original report described associated faunal remains, these were later radiocarbon dated and found to be much younger, $<2000$ cal BP (Woodman et al. 1997). Unfortunately, the location is now reclaimed and buried below Belfast City Airport. The latter site also consists of a lithic scatter, probably of Later Mesolithic age, found on intertidal muds (Fig. 11.8). Underlying this is a peat deposit dated to c. $6800-6600 \mathrm{cal}$ BP though whether the lithics and peat are associated is not confirmed (Woodman 1978). Unlike Sydenham, recent visits (2014) show that the site still exists, and relatively fresh lithic material is still present on the intertidal mud, along with traces of the peat. Sites like these could be taken as hints of the archaeological record potentially located further offshore, as demonstrated at Eleven Ballyboes (see above and Westley 2015). In other cases, it is possible that archaeological material in the intertidal zone has washed down from eroding deposits above high water or may be a remnant lag from eroded sites on the foreshore, and these possibilities would require field assessment to confirm.

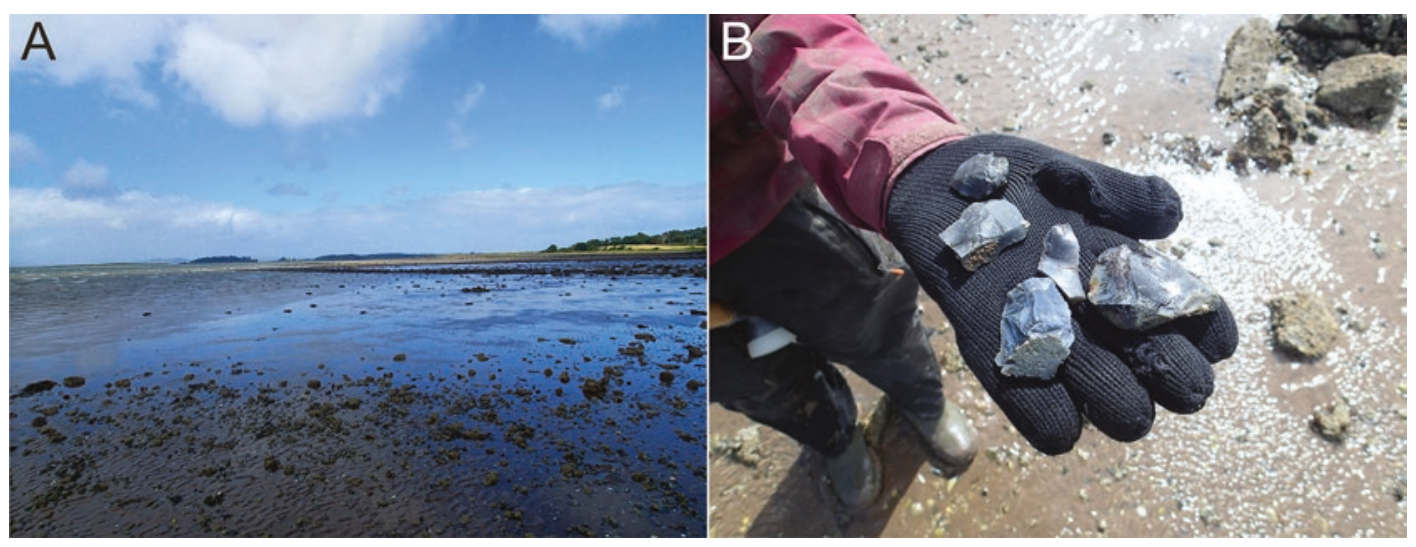

Fig. 11.8 (a) View looking across the intertidal zone at Big Stone Bay and Strangford Lough at low water. (b) Later Mesolithic finds collected from intertidal mud surface at Big Stone Bay. Photos by K. Westley 


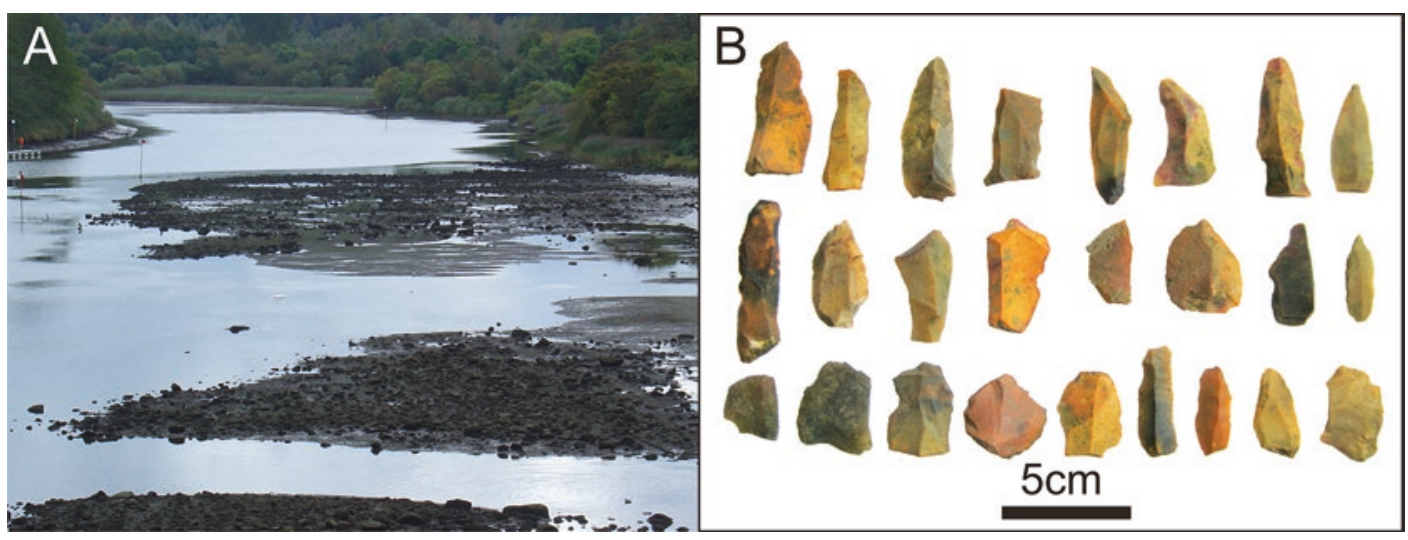

Fig. 11.9 Bann Estuary, Co. Derry. (a) Sandelford site exposed during extreme low water. This site is located below Mount Sandel-the earliest dated occupation site in Ireland. (b) Mesolithic flints recovered from the intertidal zone at Sandelford. Photos by R. McConkey

A few sites are also located in upper estuarine locations, most notably at Sandelford in the Bann Estuary adjacent to Mount Sandel (Fig. 11.9). Here, a ridge protruding partly across the river is exposed at low water and has produced a collection of several hundred lithics similar to those from Mount Sandel itself, i.e., Earlier Mesolithic (Woodman 1978, 2015). Smaller quantities of lithic material (tens of finds) have also come from the intertidal portions of the River Foyle at Ballynagard and Culmore.

The evidence described so far is overwhelmingly lithic. However, at one location on the beach at Glynn (Larne Lough), a portion of a pointed bone implement was found. Although it has not been radiocarbon dated, it is similar to items interpreted as the tips of fishing spears or eel rakes which have been dredged from the nontidal part of the River Bann upstream of Mount Sandel (the Cutts locality). Dates on these items consistently place them to between c. 9000 and $7500 \mathrm{cal}$ BP (Woodman 2015). The location of the Glynn find spot may be significant in that nearby raised beach deposits contain both Earlier and Later Mesolithic lithics apparently washed up from further offshore (see below). Along with a worked wooden plank from the Shannon Estuary dating to c. $6700 \mathrm{cal} \mathrm{BP}$, these remain the only known organic artefacts of Mesolithic age from exposed intertidal landscapes (O'Sullivan 2001). Note though that organic remains from buried landscapes are known (see below for discussion of the North Wall Quay fish traps).

As RSL stabilised round the northern coast of Ireland as late as $6000 \mathrm{cal} \mathrm{BP}$, one might expect that much of the material recovered from beaches would date to the Later Mesolithic. However, some of the recovered assemblages contain elements such as distinctive flake axes and core axes which belong to the first thousand years of the Irish Mesolithic. Thus, the pattern is suggestive of activity around a number of the outer estuaries and sea loughs during the Later Mesolithic and perhaps also in the Earlier Mesolithic. Given that RSL was lower, this was not directly on the shore but on higher ground overlooking coastal and estuarine floodplains.

Intertidal collections are largely absent outside the north and north-east coasts barring material from Connemara in the west of Ireland (generally stone axes, probably of Later Mesolithic affinity), which has reportedly been washed up during recent winter storms and, in one instance, may be associated with an intertidal peat deposit (M. Gibbons, pers. comm.). Whether this relates to a true absence of evidence or simply a lack of recognition of the relevant evidence is presently uncertain.

Aside from the Mesolithic evidence, finds dating to the early Neolithic have also been made in intertidal localities. This includes organic artefacts found in the intertidal zone of the Shannon 

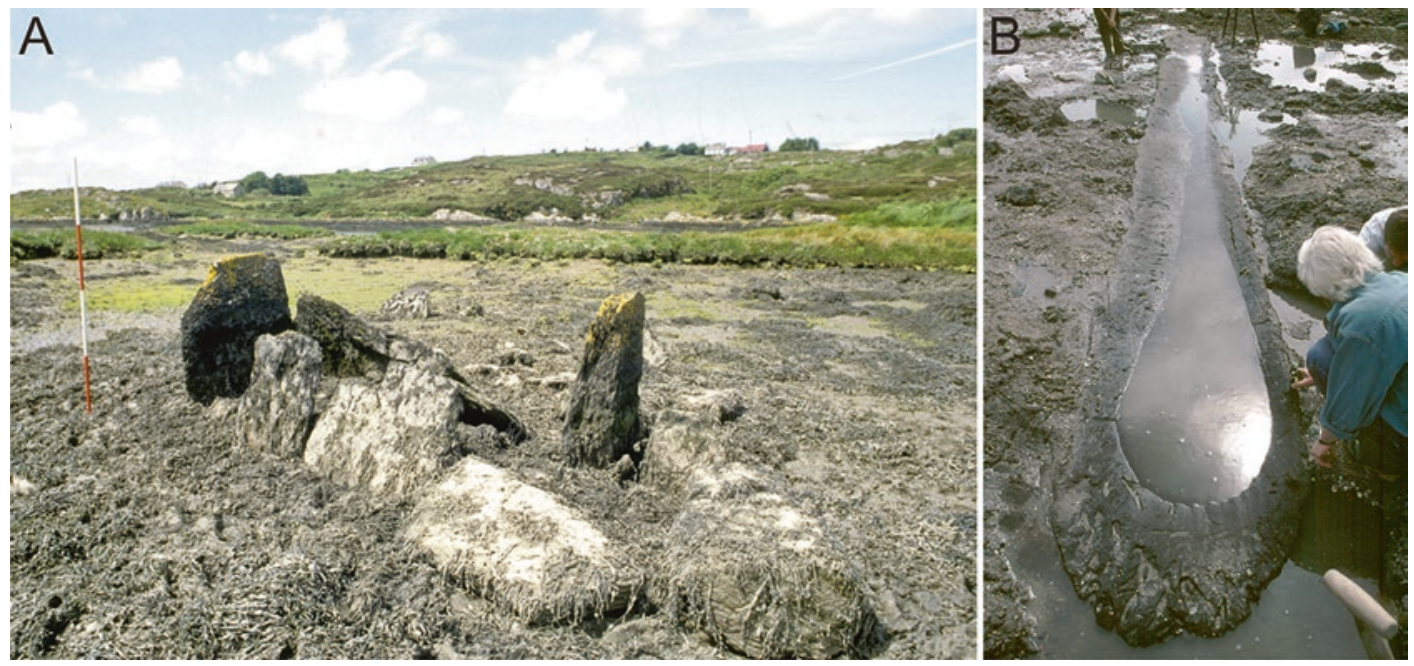

Fig. 11.10 Neolithic finds from the intertidal zone. (a) The Lag: Megalithic tomb in the intertidal zone, Co. Cork. (b) Logboat in intertidal mud, Strangford Lough, Co. Down. Photos by P. Walsh; McErlean et al. (2002)

Estuary, such as human remains and a woven basket, both dating to around 5700-5400 cal BP, while an intertidal scatter of lithics, bone and organic artefacts at Carrigdirty, also in the Shannon Estuary, has been interpreted as a possible Early Neolithic occupation site (O'Sullivan 2001). A logboat of similar age (5500-5000 cal BP) was also found in intertidal mud in Strangford Lough (Fig. 11.10b; McErlean et al. 2002). The Neolithic is also represented by two megalithic tombs on the south-west coast at Cork Harbour and Ringarogy Island. Both were presumably built on dryland but are now situated in the intertidal zone (Fig. 11.10a; Power 1994; Shee Twohig 1995). Their location in the far south-west fits the GIA-modelled pattern of RSL change in that this area was the last to attain modern sea level.

\subsubsection{Raised Beach Archaeological Finds}

The term 'raised beach' refers to palaeoshoreline features, generally consisting of sands and gravels sometimes with marine shells, found on land above present sea level. They represent former coastal, intertidal or nearshore environments left high and dry by RSL fall. In north-west Europe, the principal mechanism behind this is glacio- isostatic uplift, and hence raised beaches concentrate where the LGM ice was thickest and longest lasting (e.g., Scotland, Scandinavia). In Ireland, post-LGM raised beaches are found principally around the north-east coast owing to its greater degree of isostatic recovery and include Late Pleistocene and mid-Holocene examples (Edwards and Craven 2017; Westley and Edwards 2017; see previous section; Fig. 11.1). In particular, the mid-Holocene raised beach is frequently associated with water-rolled flint artefacts which derive from coastal sites, primarily of Later Mesolithic age. Notable examples include sites at Curran Point (Movius et al. 1953/54), Port of Larne (Woodman 2012) and Cushendun (Movius et al. 1940/41).

Raised beach sites, though not currently submerged, have been included in this review because they represent archaeological material which was once inundated and therefore subject to coastal and marine processes. As such, they give an impression of the likely nature of the archaeological evidence which might be found offshore. At the Curran Point, for instance, thousands of water-rolled lithics have been recovered, concentrated mainly in storm beach shingle but also including fresher or unrolled implements from underlying sands and gravels representing former foreshore sediments (Movius et al. 
1953/54). In other cases, raised beach deposits may also bury older Earlier Mesolithic deposits. At Cushendun, fine-grained sediments (the lower lagoon silts) are interpreted as a sheltered estuarine environment (Movius et al. 1940/41) and contain flint implements and organic remains dating to c. 8000-9000 cal BP. These occur beneath c. $7-8 \mathrm{~m}$ of stratified gravels, silts and sand which are variously interpreted as relating to marine transgression, coastal barrier migration and possibly breaching (Roe and Swindles 2008). The overlying sediments also contain horizons of lithics (including Later Mesolithic to Neolithic forms) that tend to be rolled and patinated in contrast to the Earlier Mesolithic finds which are regarded as in situ or, at least, not transported very far (Movius et al. 1940/41; Woodman 1978). Finds of a similar age were also made at the Port of Larne site where two chipping floors, flint implements and a series of pits and hollowssome containing organic remains such as fish bones, hazelnuts and charcoal-were found under several metres of beach shingle. Radiocarbon dates indicate multiple phases of activity ranging from c. 9200 to 7500 cal BP (Woodman 2012).

At worst, raised beach sites indicate that although archaeological deposits on the waveswept Irish coast are not obliterated by marine transgression, much of the evidence will be heavily reworked (e.g., the storm beach deposits of the Curran Point or the Upper Gravels at Cushendun). At best, they show that better preservation is possible and that significantly variable taphonomic conditions can occur in even a single locality. This ranges from variation between rolled and near-fresh lithics in the Curran Point sands and gravels to the fine-grained lower lagoon silts at Cushendun and the intact chipping floors with faunal and fish remains preserved under beach shingle at the Port of Larne. This is encouraging for the preservation of similar evidence offshore. Moreover, the presence of material within a raised beach could hint that a source deposit is buried offshore in a similar fashion to the intertidal material discussed above. This appears to be the case at Glynn (Larne Lough) where Earlier Mesolithic flints have been found in raised beach sands and gravels apparently washed in from a source deposit submerged in a small adjacent bay (Woodman 1977). The assumption of course is that the locale was persistently attractive to past humans over a long period of time including through an interval of RSL rise.

\subsubsection{Intertidal, Submerged and Buried Organic Remains}

The most widespread evidence indicative of prehistoric landscape preservation on the Irish seafloor comes from the intertidal zone. Dotted around the Irish coast are numerous peat and forest remains exposed at low tide (Charlesworth 1963; Mitchell 1976). Many sites are found in low-energy sheltered bays and estuaries, such as Strangford Lough and the Shannon Estuary (O'Sullivan 2001; McErlean et al. 2002). However, there are also sites located on more exposed and higher-energy coastlines, such as Portrush on the north coast (Fig. 11.11; Wilson et al. 2011), and various localities on the Atlanticfacing west coast, which are periodically exposed after beach stripping by storms (Williams and Doyle 2014; O'Connell and Molloy 2017; M. Gibbons pers. comm.).

At a handful of sites, peats have been found below the low-water mark, either brought up by dredgers and cores or reported by divers. Known sites include Portrush West Bay (Westley et al. 2014), the Bann Estuary (Carter 1982), Allihies (Breen 1993), Lough Swilly (O'Raw 2003) and Eleven Ballyboes (see above; Westley 2015). These are a strong indication that remnants of the past landscape can be preserved in fully subtidal environments. Radiocarbon dates from these intertidal and subtidal deposits give ages from as early as 13,500 cal BP right up to 5000 cal BP (Brooks and Edwards 2006).

A few locations have also produced faunal remains. For example, Roddans Port on the north-east coast has produced reindeer (Singh 1963; Morrison et al. 1965), red deer have been found in the intertidal portions of the Shannon Estuary (O'Sullivan 2001) and a portion of red 


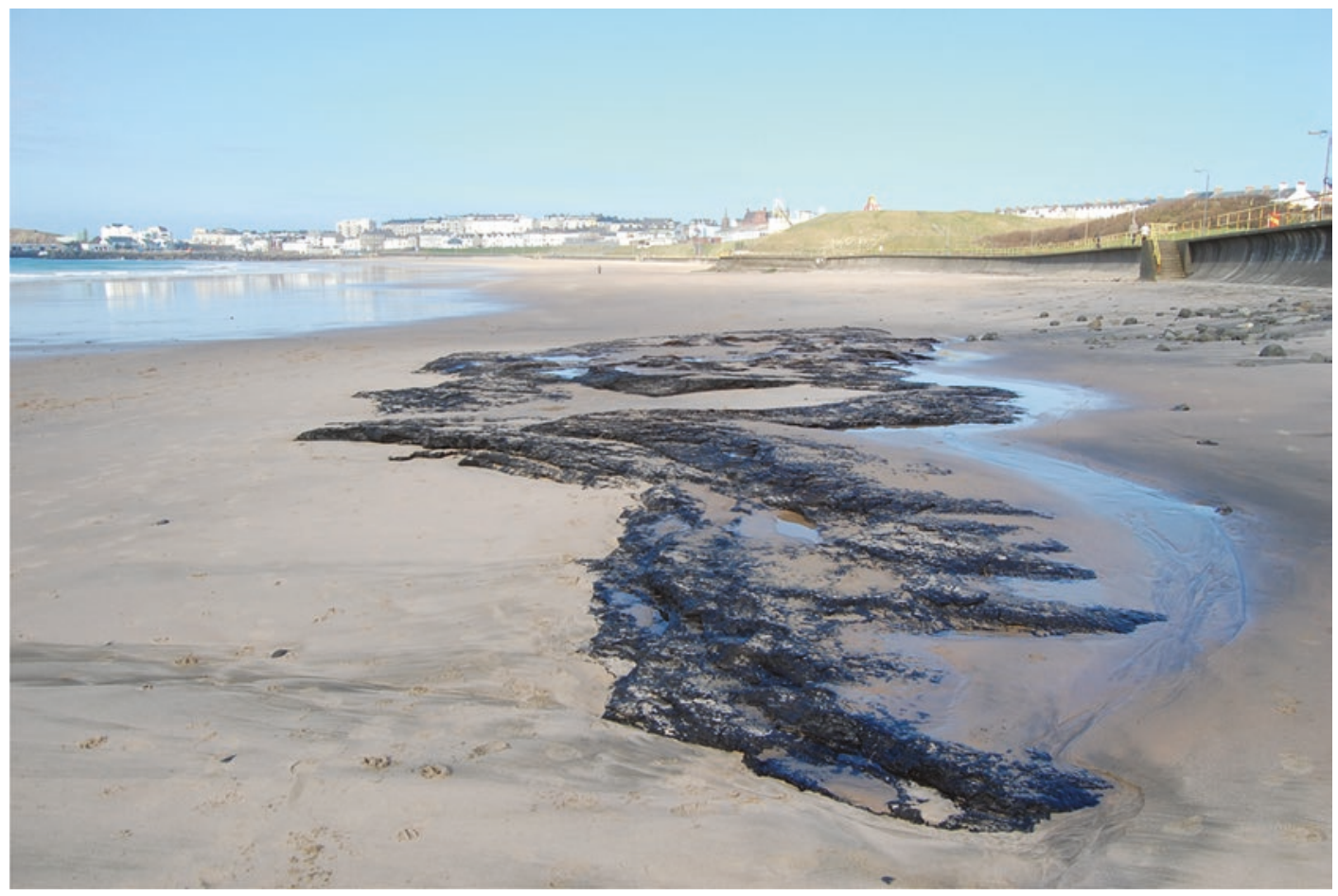

Fig. 11.11 Bed of intertidal peat exposed on the beach at Portrush (West Strand), Co. Antrim. This particular site has been radiocarbon dated to between 7400 and 6500 cal BP. Photo by K. Westley

deer antler was washed up on a beach at Ventry, Co. Kerry (Woodman et al. 1997). At least two subtidal localities have also produced large Pleistocene mammal remains, namely, an undated mammoth tusk dredged from Waterford Harbour (Monaghan 2017) and a possible mammoth humerus dredged from Galway Bay (Adams 1883). Note, however, that identification of the latter has not been verified, and Savage (1966 p. 123) states that it is 'more likely to be that of a circus elephant than a mammoth'. These are the only presently known large mammal remains from submerged Irish landscapes, and the paucity of finds is a marked contrast to the extensive palaeontological collections from the North Sea (Cohen et al. 2017; Bailey et al., Chap. 10, this volume; Peeters and Amkreutz, Chap. 8, this volume).

Additional organic evidence from below present sea level (though not necessarily underwater) has come from deep excavations or borehole sampling on reclaimed land. Particularly welldocumented land surfaces include an extensive peat sequence buried as deep as $-15 \mathrm{~m}$ below present sea level around Belfast Lough and radiocarbon-dated to c. 11,100-9500 cal BP (Manning 1970; Carter 1982; Brooks and Edwards 2006). Even older evidence comes from the south-west of Ireland (Cork Harbour) in the form of series of estuarine or intertidal organic clay silts at c. $-17-35 \mathrm{~m}$ depth. These are particularly significant as they date from a temperate stage preceding the Last Interglacial (MIS 5), potentially the MIS 11 or MIS 9 interglacials (Dowling et al. 1998; Coxon et al. 2017).

Similar deposits can also survive offshore. For example, Plets et al. (2015) sampled buried finegrained organic-rich estuarine/intertidal sediments dated to c. 13,300-13,400 cal BP from the inshore part of Bantry Bay (Co. Cork). Using seismic profiles, they also identified an even more deeply buried deposit stratified under glacial material and, from its acoustic characteristics, suggested it was deposited in a low-energy estuarine or lacustrine setting (Plets et al. 2015). Tentative correlations were made with a freshwa- 
ter organic-rich silt identified in boreholes from the same area by Stillman (1968). Though originally regarded as Allerød/GI-1 in age (c. 13-14 ka cal BP), this assignation was based solely on pollen zonation, and it may be that it actually represents an earlier interglacial, as in Cork Harbour (Plets et al. 2015).

Most buried organic deposits have produced only palaeoecological or, in a few cases, palaeontological evidence, such as red deer, boar and giant deer (Megaloceros) excavated from Belfast Harbour (Praeger 1892; Savage 1966). However, their archaeological potential is well illustrated by the discovery of Later Mesolithic wooden fish traps during construction work at Spencer Dock, North Wall Quay, Dublin (Fig. 11.12). These were found buried under reclaimed land at a depth of c. $6.3 \mathrm{~m}$ below present sea level on what was once the bank of the Liffey Estuary or a tidal island. They consist of a

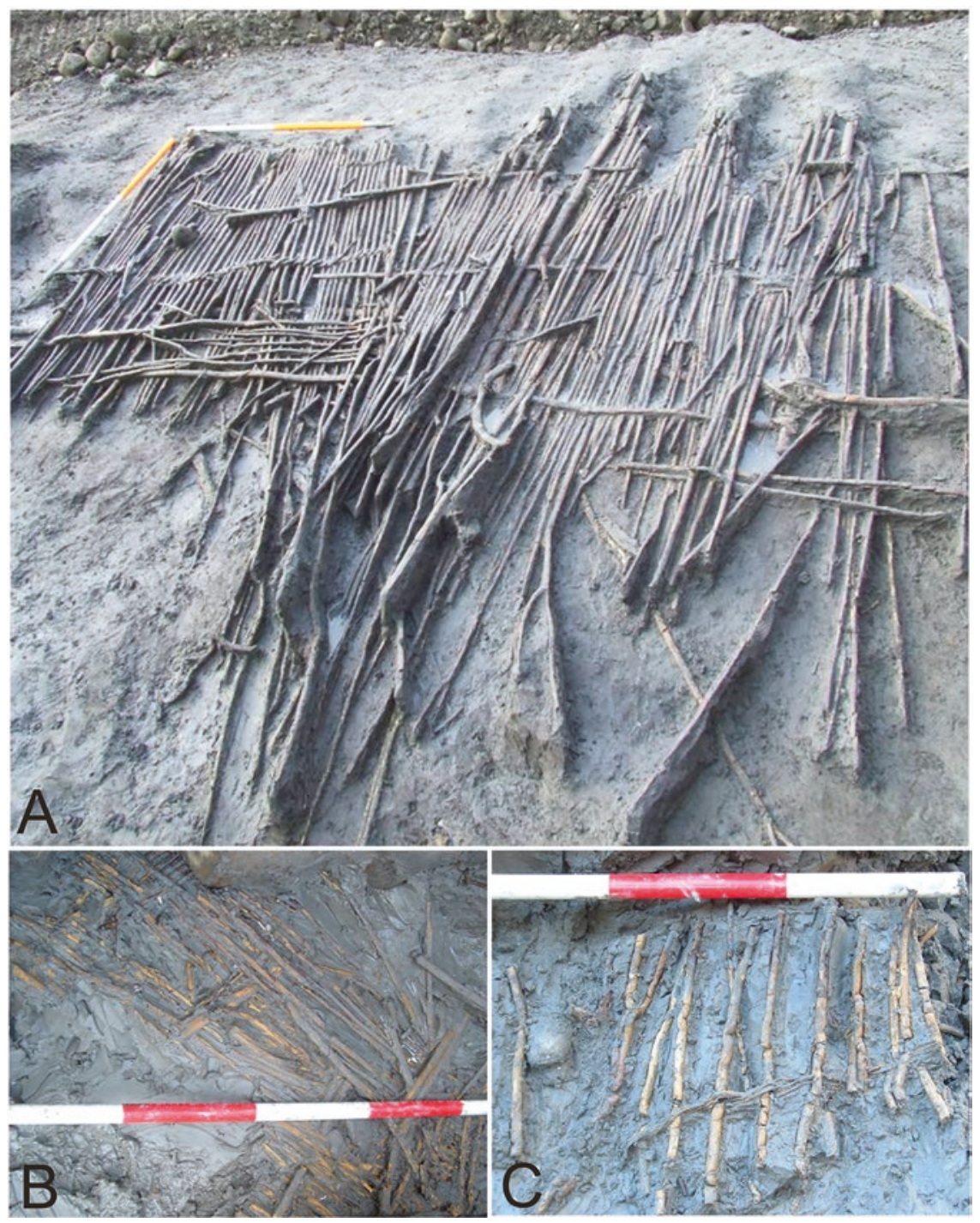

Fig. 11.12 Prehistoric fish traps found buried $6.3 \mathrm{~m}$ below present sea level at North Wall Quay, Dublin. (a) Neolithic weir (5600-5400 cal BP) comprising wattle panels supported by large stakes and bound by hazel withies. (b) Detail of horizontal panel from a wattle trap (8040-7840 cal BP). (c) Detail of C-shaped trap (8030-7790 cal BP) showing vertical rods and binding withies (scale intervals are $20 \mathrm{~cm}$ ). Photos by M. McQuade 
complex of up to five well-preserved partly broken traps made of hazel stakes, wattle fencing and baskets. Identified traps included up to three ebb weirs, a basket trap and a C-shaped trap. All appear to have been designed to catch fish on the falling tide. Radiocarbon dates place them between c. 8100 and 7700 cal BP (McQuade and O'Donnell 2007). A Neolithic fish trap dated to c. 5600-5400 cal BP was also found at a higher level at this site (McQuade 2008).

\subsection{Discussion}

The above clearly demonstrates that fragments of submerged landscape and associated archaeology are known from all around Ireland. Nevertheless, it is also apparent that Ireland lacks the extensive palaeolandscape and palaeontological records of the North Sea (Cohen et al. 2017; Peeters and Amkreutz, Chap. 8, this volume) or the unparalleled archaeology of the Baltic (Fischer 2011; Lübke et al. 2011; Bailey et al., Chap. 3, this volume; Nilsson et al., Chap. 4, this volume; Jöns et al., Chap. 5, this volume).

This leads to three key questions. Firstly, why has relatively little submerged landscape evidence been found in Ireland? Secondly, even if more evidence remains to be discovered, would it usefully contribute to our understanding of early Irish prehistory? Thirdly, if deemed worthy of investigation, what are the most effective strategies of investigation?

\subsubsection{The Lack of Evidence}

It is not worth trying to find a single overarching reason for the paucity of Irish submerged landscape evidence. The reality is that a number of factors likely contribute and which one(s) is/are the most important cannot be determined at present.

Taphonomy has undoubtedly played a part (Westley and Edwards 2017). Much of the Irish coastline is typified by high-energy conditions, particularly the Atlantic-facing south, west and north coasts. Storm impacts can be considerable, and there are many examples of beach stripping and coastal erosion (e.g., Kandrot et al. 2016). Even in the more sheltered Irish Sea, there are zones of strong tidal currents, particularly at the narrow straits of the North Channel and St. George's Channel (Evans 1995; Atkins 1997). Offshore, high-seabed sediment mobility in response to wave and tidal forcing is well documented by mobile bedforms (e.g., Evans et al. 2015). From this, the expectation would be that preservation of prehistoric sites and palaeolandscapes is poor. While likely true for many areas, this is not universal. There is sufficient complexity in the Irish coastline, with numerous bays, inlets and - particularly on the west coastislands, to create variation in energy levels and taphonomic conditions. Moreover, the above evidence shows that palaeolandscape fragments can be preserved even in high-energy environments, such as the intertidal peats on the wave-swept north and west coasts, as well as in lower-energy inlets and estuaries. It is more likely that pockets of preservation rather than total absence will be the norm. Thus, it can be reasonably argued that the lack of fully subtidal evidence may stem from factors other than destruction by rising sea levels.

One additional mitigating factor is the extent of land exposed during the RSL lowstand. The depth of the lowstand, coupled with the bathymetry of Ireland's shelf, means that maximal subaerial exposure may never have been more than c. $30 \mathrm{~km}$ out from the present coastline (Fig. 11.2; Brooks et al. 2011). This contrasts with Britain where the shallow North Sea and English Channel provided a vast landscape open to prehistoric settlement. Even within the Irish Sea itself, bathymetry is such that the largest expanses of land were on the British side of the central channel (Brooks et al. 2011; Sturt et al. 2013). Simply put, the larger expanse of these areas means that the likelihood of settlement, and consequently the preservation of archaeological evidence and the chance of discovery, is greater.

Another reason could relate to the history of research. It has long been recognised that prehistoric sea levels were lower-largely due to intertidal forests and deeply buried peats (e.g., Praeger 
1891; Stewart 1911). However, the earliest antiquarians and archaeologists were concerned primarily with the raised beach sites of the north-east (e.g., Coffey and Praeger 1904/05; Movius et al. 1953/54). It was not until the 1990s that efforts were made to systematically undertake maritime archaeology in Ireland and, even then, attention focused on shipwrecks (Breen and Forsythe 2001). The exceptions were the major intertidal surveys of Strangford Lough and the Shannon Estuary (O'Sullivan 2001; McErlean et al. 2002), but even these projects, which did identify intertidal archaeological and palaeolandscape evidence, were multi-period surveys with submerged palaeolandscapes forming part of a body of work. It is only within the last decade that a concerted effort has been made to investigate Irish submerged landscapes (Bell et al. 2006; Westley et al. 2011a, b, 2014; Westley 2015). Even this though has focused almost exclusively on the north coast, and the rest of Ireland has never been fully investigated beyond palaeoenvironmental investigations of a handful of intertidal peats (e.g., Whitehouse et al. 2008; Simpson 2008; Williams and Doyle 2014; O'Connell and Molloy 2017).

A final, more speculative, reason could include the nature of commercial activities on the Irish shelf. The two main industries responsible for the vast majority of chance finds (mainly palaeontological, but also including some archaeological remains) around the British Isles are offshore aggregates extraction and trawling. Aggregates extraction has produced a number of recent finds, not least the Area 240 handaxes off Great Yarmouth (Tizzard et al. 2011; Bailey et al., Chap. 10, this volume). In Irish waters, aggregate deposits suitable for extraction have been identified in the Western Irish Sea, but extensive commercial extraction has not taken place (Highley et al. 2007; O'Mahony et al. 2008). Trawling, particularly beam trawling for flatfish, was historically, and remains, the main source of finds in the Dutch sector of the North Sea (Van Kolfschoten and Laban 1995; Mol et al. 2006; Peeters and Amkreutz, Chap. 8, this volume). The same was true of the British sector until the decline of the fishing industry (Bynoe et al.
2016). One possibility, yet to be verified, is that differences in the Irish fisheries are responsible for the lack of finds. For example, large sectors of the northern Irish Sea fishery focus on the Dublin Bay prawn (Gibson 2011). This species is concentrated in deep water $(>30 \mathrm{~m})$ muddy substrates which were probably not exposed during the RSL lowstand and therefore not a likely source of prehistoric finds. Other parts of the Irish shelf, however, are trawled, and it remains to be determined if the lack of finds is a product of different gear (e.g., Irish fishermen primarily use otter trawls rather than beam trawls; Davie and Lordan 2011; see also Maarleveld, Chap. 26, this volume), a lack of recognition of recovered archaeological/palaeontological finds or a true lack of evidence. All the above are speculative and need further research to confirm but suggest legitimate reasons as to why submerged prehistoric evidence is lacking, as well as equally valid reasons to suspect that evidence exists but remains undiscovered.

\subsubsection{Contribution to Knowledge}

The oft-cited reasons for investigating submerged archaeological landscapes-namely, their ability to provide unique evidence (in some cases including organics preserved by waterlogging) pertaining to coastal and marine adaptations, seafaring and past human responses to sea-level change (Bailey and Flemming 2008; Bailey 2014) apply also to the Irish situation.

\subsubsection{Seafaring}

That Ireland was apparently not connected to Britain from at least 15,000 cal BP onwards (Brooks et al. 2011) implies that its Mesolithic settlement was accomplished by people with the ability to make seagoing journeys. This is substantiated by Earlier Mesolithic flints from Inishtrahull (Woodman 2015). This small island is located c. $7 \mathrm{~km}$ north of Malin Head (Ireland's most northerly point) and is separated by sufficiently deep water to have remained cut off during the RSL lowstand. Once established in Ireland, the seafaring tradition was maintained, 
as evidenced by the Later Mesolithic occupation of Rathlin Island, like Inishtrahull cut off by several kilometres of deep water (Quinn et al. 2012), and also Later Mesolithic-type material from the Isle of Man and Neolithic contacts across the Irish Sea (Garrow and Sturt 2011).

The circumstantial evidence for seafaring reveals a number of things about Ireland's early colonists. Firstly, the occupation of Inishtrahull and Rathlin suggests an ability to cross the exposed, often treacherous waters of the Atlantic seaboard as well as coping with the more sheltered waters of the Irish Sea. Secondly, boats carried more than just people. Transport of animals may also have played a major role both in enabling permanent Mesolithic settlement in Ireland and later in the Neolithic transition to agriculture. Wild boar in particular is not present in Late Glacial faunal assemblages, and their later appearance in the early Holocene coincident with Mesolithic settlement is suggestive of a deliberate introduction (Montgomery et al. 2014; Warren et al. 2014; Monaghan 2017). This could have been a response to the absence of large game such as red deer, aurochs and elk, which were available in Britain but not Ireland (Woodman 2015; Warren 2017). Later in the Mesolithic and Neolithic, the appearance of new domestic species (e.g., cattle appear by c. 6300 cal BP) and also red deer from c. 5000$4500 \mathrm{cal} \mathrm{BP}$ onwards are clear signs of seaborne transport of animals (Montgomery et al. 2014; Monaghan 2017).

Less clear are the boats and the routes used to reach Ireland. Hundreds of Irish logboats have been found and range in date from the Mesolithic to the post-Medieval (Fry 2000). However, the vast majority are from inland waterways, and clearly seagoing crafts are not known from either the Mesolithic or Neolithic. In terms of Mesolithic crossings, Woodman (2015) has suggested three potential routes to Ireland, firstly from Scotland across the North Channel, secondly across the Isle of Man Basin and finally from Wales to south-east Ireland. Note though that these are direct journeys across the Irish Sea and do not account for oceanographic conditions of the time (e.g., tidal currents and dominant wind direc- tions). It may be that short- and long-distance 'coastal tramping' along a north-south axis constrained by tidal currents, as envisaged by Garrow and Sturt (2011) for the Neolithic, may be a more appropriate analogue.

There are also questions regarding the nature and frequency of contact between Ireland, Britain and the outlying islands. In the Neolithic, there must have been seafaring networks across the Irish Sea, suggested by the movement of people, animals, objects and ideas and exemplified by the transition to agriculture, the Neolithic axe trade (including distinctive porcellanite axes sourced from north-east Ireland) and similarities in monument and pottery types (Garrow and Sturt 2011; Cooney et al. 2012). The situation in the Mesolithic is less clear. Individual finds such as the Ferriter's Cove cow bones indicate some contact by the final Mesolithic, but in general, the supporting evidence for maritime networks is rare. One of the central questions in the Irish Mesolithic has been the transition to a very different technique of stone working after c. 88008600 cal BP which is not paralleled in Britain but is found on the Isle of Man. The absence of British equivalents can be interpreted in two ways. Firstly, as an indication of isolation from Britain and very limited maritime networks. This, however, is at odds with the evidence for seafaring described above, including the Isle of Man material. Alternatively, it might be taken as evidence of deliberate cultural differentiation in response to high levels of maritime connectivity (Garrow and Sturt 2011; Cooney et al. 2012; Bell and Warren 2013; Warren 2015a, 2017).

What was taking place in the Late Glacial, to enable brief exploratory journeys, as suggested by the Alice and Gwendoline Cave patella (Dowd and Carden 2016), is also uncertain. Stable isotope evidence for the presence of marine resource-using populations at Kendricks Cave, North Wales (Richards et al. 2005), hints at a marine adaptation in the Irish Sea region but how this translates to seafaring is not clear. Recent discoveries of Ahrensburgian-type material (latter half of GS-1 to earliest Holocene) have been made on the Scottish island of Islay (visible from Northern Ireland on clear days). Despite slightly 
lower RSL, boats were necessary to reach Islay (Mithen et al. 2015), supporting the premise that Late Glacial populations were capable of seagoing or at least island-hopping voyages. An ability to cross even greater distances to reach Ireland would provide greater substantiation of the maritime abilities of these hunter-gatherers. Indeed, that such abilities were present is perhaps unsurprising in light of the extensive but indirect evidence from Scandinavia (the majority of Fosna/ Hensbacka sites are located on palaeoshorelines, outer coasts and islands from c. 11,70011,500 cal BP onwards in western Sweden and Norway) indicative of boat use and suggestive of seal hunting (Schmitt 2015; Schmitt and Svedhage 2015; Bjerck 2017) and the hypothesised links between Scandinavian Fosna/ Hensbacka and Scottish groups across the Doggerland region during the GS-1/Holocene transition (Warren 2015a; Ballin and Bjerck 2016).

The ephemeral nature of seafaring and its attendant evidence makes it hard to address these questions. Nevertheless, certainly for the earlier parts of the period of study, the lack of information from contemporaneous shorelines where boats were built, launched and made landfall makes it very difficult to get definitive answers.

\subsubsection{Coastal Adaptation and Initial Colonisation}

One of the long-standing unresolved questions of Irish archaeology is the delay in human occupation relative to mainland Britain. While the preLGM absence is probably partly explicable by taphonomy and Ireland's peripheral location, the Late Glacial and Mesolithic delay is more uncertain, certainly in light of the observation (see above) that sea crossings were probably not an obstacle (Warren 2015a).

If the Alice and Gwendoline Cave patella (c. $12,800-12,6000 \mathrm{cal} \mathrm{BP}$ ) is secure evidence of a pioneer incursion into Ireland, then Late Glacial populations were present in Britain at least 2000 years earlier. Reasons postulated for the delay centre on the impoverished nature of the Late Glacial Irish fauna, which lacked large her- bivores other than giant deer (Megaloceros giganteus), small numbers of reindeer (but only towards the end of the GI-1 interstadial) and possibly red deer (Montgomery et al. 2014; Monaghan 2017). Crucially, horse, a key resource for British Late Glacial hunters, was absent from Ireland (Woodman 2015; Warren 2015a, 2017).

If one assumes that the British Isles were largely depopulated during the GS-1/Younger Dryas cold snap, then Ahrensburgian hunters had returned by c. 12,000 cal BP, and British Early Mesolithic populations were in place by $\mathrm{c}$. $11,500 \mathrm{cal} \mathrm{BP}$. Once again, there is a delay of $\mathrm{c}$. 1500-2000 years until the colonisation of Ireland, represented by Mount Sandel. Pioneer incursion cannot be ruled out, as implied by the second cutmarked bear bone from Alice and Gwendoline Cave (11,000-10,400 cal BP), but full settlement does not appear to have taken place until after 10,000 cal BP. Again, this delay is generally viewed as product of Ireland's distinctive ecology, with no large ungulates surviving the Younger Dryas (Montgomery et al. 2014; Woodman 2015; Warren 2017).

The absence of large game may have been a deterrent to land-based hunters, both in the Late Glacial and Early Holocene. Therefore, it may be that deliberate importation of species such as wild pig by boat was needed to enable full settlement (Warren 2015a, 2017). However, if incoming populations had some degree of coastal adaptation, as suggested by the circumstantial evidence for seafaring, and the capacity to construct fish traps such as found in the Liffey Estuary (McQuade and O'Donnell 2007), the absence of large game might be expected to be less of a deterrent. The caveat is that we simply do not know what the marine and coastal ecology of the Irish coastline was like in the Late Glacial or aftermath of the GS-1/Younger Dryas and thus what resources were actually available (Woodman 2015). Linked to this are questions of when migratory species such as salmon or eels began to establish themselves in Irish rivers and estuaries. Effectively, while the technical challenge of seafaring may have been overcome, it is an open question as to whether the coastal envi- 
ronment was attractive or supportive of permanent long-term settlement until later in the Holocene.

With the gaps in the archaeological and marine palaeoecological records on both sides of the Irish Sea, it is difficult to see how this question can be resolved. There is no certainty that submerged sites can provide the necessary evidence, but without coastal evidence dating to the Late Glacial and Earlier Mesolithic, we cannot even begin reconstructing the ecological affordances of the coastline and inshore waters.

\subsubsection{Coastal Change and Human Response}

The presence of a maritime adaptation during the permanent settlement of Ireland is substantiated by saltwater fish remains at a handful of sites, chiefly Mount Sandel and Port of Larne for the Earlier Mesolithic and Ferriter's Cove, Baylet and Rockmarshall for the Later Mesolithic (Warren 2015b; Woodman 2015). The latter three sites also have associated shell middens. However, the extant evidence for this maritime adaptation is still sparse; fewer than ten sites have substantial quantities of saltwater fish remains, and there are no shell middens with confirmed dates to the Earlier Mesolithic (Milner and Woodman 2007). Moreover, only one coastal site has preserved fishing gear (North Wall Quay fish traps), though basket fish traps are also known from the inland lake site of Clowanstown. Fish remains were not found at North Wall Quay, but it is likely that exploited species included estuarine (e.g., herring, whiting, bass, sole, flounder, among others) and migratory ones (e.g., eel, salmon) (McQuade and O'Donnell 2007). Estuarine exploitation of migratory species is also suggested by the Cutts bone points (Warren 2015b; Woodman 2015). Marine mammal remains are also rare, with seal found only at Dalkey Island (Warren 2015b). Stable isotopes on human bone from Ferriter's Cove and a dog bone from Dalkey Island indicate a heavily marine-based diet, but on the other hand, human bones from elsewhere such as Killuragh Cave (inland), Rockmarshall (coastal) and Loughan (inland riverine) indicate a more balanced marine-terrestrial diet (Warren 2015b; Woodman 2015).

Notwithstanding the need to be wary of ascribing a single dietary adaptation to the whole island and entire Mesolithic (Woodman 2015), this lack and the spatio-temporal distribution of evidence raises two issues. Firstly, is it a product of submergence or erosion of coastal sites by rising sea level? Secondly, could rising sea level during the early Holocene have led to changing practices during the Mesolithic as coastal palaeolandscapes themselves changed in response?

Regarding the first issue, there are spatiotemporal disparities in the distribution of evidence across Ireland which suggest this is a possibility. For instance, in south-west Ireland, Ferriter's Cove was for many years the only site with evidence of coastal use (Woodman et al. 1999; Milner and Woodman 2007). This has since been supplemented by recent excavation of a final Mesolithic shell midden at Fanore (Lynch 2013). While this is undoubtedly a product of historical factors, such as a heavy focus on the north-east (Woodman 1978, 2015), it also mirrors the predicted deepening of the RSL lowstand from north-east to south-west, in that the greatest concentration of coastal sites has been found where the least land has been inundated (the north-east) and vice versa (i.e., south-west). That Ferriter's Cove and Fanore date to the final Mesolithic could be taken as an indication that earlier coastal evidence from the south-west is concentrated underwater. In contrast, the earliest dated sites with saltwater fish remains are Port of Larne and Mount Sandel, both located in the north-east relatively close to the contemporaneous shoreline because the lowstand was shallower. The absence of Earlier Mesolithic shell middens, which might be expected to have been created near the coast, supports this in that RSL was universally lower in the early Holocene and thus the relevant shorelines are now underwater.

The second issue is presently more speculative and harder to assess, particularly in light of the missing coastal parts of the record which make it hard to directly compare different time intervals. Nonetheless, we must consider that the early inhabitants of Ireland were living at in time 
of rapid RSL rise. Therefore, what might have been the response to flooding of river valleys to create extended inlets and embayments? Might the creation of larger areas of shallows and wetlands have increased the resources of shallow inshore waters and hence attracted increased coastal exploitation made possible by use of standing gear like the Dublin fish traps (McQuade and O'Donnell 2007)? Alternatively, could there have been an increased focus on topographic prominences, such as headlands, which were raised above rising sea levels and storm waves (e.g., Westley et al. 2014)? The likelihood is that different coastal landscapes had different resources and were used in different ways. However, without accurate reconstructions of what specific areas looked like or offered in resource terms, it becomes difficult to understand how regional strategies varied over time.

\subsection{Future Research}

If the argument that submerged landscapes can usefully contribute to Irish prehistory is accepted, then how can they be investigated? Given the rather limited archaeological and palaeoenvironmental evidence base, the key aim at this stage should be to enhance it.

With this in mind, the first issue to consider is which areas have the best prospects for finding submerged evidence. The likelihood is that submerged sites, if preserved, would be found at a range of depths around Ireland due to the varying pattern of RSL rise. In the north-east, extant models and raised beach evidence suggest that only the Late Glacial and Earlier Mesolithic coastal landscapes are missing and would be located in relatively shallow $(<-20$ to $-30 \mathrm{~m})$ water. As one moves south and west, the timespan of potential sites will increase, and earlier sites will be submerged at progressively greater depths (e.g., down to -40 to $-60 \mathrm{~m}$ ). This is most obvious for the south coast where most traces of early settlement will lie below sea level as shown by the existence of Neolithic megalithic tombs on the intertidal shore. Given the high-energy conditions that prevail across much of Ireland's coast- line, preservation of submerged sites is most likely within sheltered bays, inlets and sea loughs where the extant intertidal record is most commonly preserved. Also, at times of lower sea level, these would have formed river valleys and estuarine locations, which seem to have been favoured places for settlement, judging from the extant intertidal and on-land record. Exploitation of such environments is also attested to by the North Wall quay fish traps (McQuade and O'Donnell 2007), but as shown by this site, archaeological material in such environments could be deeply buried as well as submerged.

The second consideration is how to go about conducting the investigation. There are four potential routes by which future work can proceed. These are not mutually exclusive, and the likelihood is that certain avenues of investigation will be more fruitful in some areas than others:

1. Start with known intertidal sites (both archaeological and palaeoenvironmental) to identify sources of archaeological material (e.g., washed up or eroded down) and determine if these extend into nearshore waters. The value of intensive work on Mesolithic intertidal sites has been demonstrated elsewhere, for example, in the Severn Estuary (Bell 2007), while working from onshore to offshore has already given us the first glimpses of Ireland's submerged prehistoric record as at Eleven Ballyboes (Westley 2015).

2. Use seabed mapping data to firm up evidence of RSL and coastal change and in turn produce more accurate palaeolandscape reconstructions that can go beyond shelf-scale depictions (Fig. 11.2). The ultimate aim would be to use these to guide archaeological investigation in deeper water and also to provide the proper landscape context needed to address some of the questions raised above. Fortunately, Ireland has one of the largest seabed mapping programs in the world (INFOMAR; Dorschel et al. 2011), and the resulting data have already been used in submerged landscape investigation (e.g., Westley et al. 2011a, b, 2014; Plets et al. 2015). However, these data have yet to be used to 
their full potential, with areas outside the north coast largely un-investigated for archaeological purposes and a focus on seabed bathymetry rather than buried stratigraphy (e.g., Westley et al. 2011a). It is certainly notable that the Irish Sea has not been subject to the same level of geological reconstruction and palaeolandscape investigation as the North Sea (Gaffney et al. 2007; Cohen et al. 2017) where such work has allowed major advances in understanding of the submerged archaeological record.

3. Conduct archival research on potential submerged evidence located in museum and private collections, as done for the North Sea by Bynoe et al. (2016). This has yet to be done in Ireland. In fact, it is genuinely unclear as to whether submerged evidence, particularly palaeontological finds, actually exists in Irish museum collections. It is possible that the paucity of material is genuinely reflective of the absence of evidence but needs further research to confirm.

4. Finally, make efforts to raise awareness among users of the seabed, particularly the commercial fishing industry and sports divers, to ensure that chance finds are recognised, recovered and properly recorded. Again, similar initiatives have been successful elsewhere, most notably the Protocols for Archaeological Discoveries for the fishing and renewables industry in British waters (Wessex Archaeology 2013; The Crown Estate 2014) and the OHCCMAPP community engagement project in the Outer Hebrides (Benjamin et al. 2014).

\subsection{Conclusion}

The extant evidence clearly demonstrates the existence of prehistoric landscapes on Ireland's coast, seabed and intertidal zone, in some instances with archaeological material in a range of preservation states from reworked to in situ. It is also clear that these landscapes comprise the coastal zones potentially occupied during Ireland's earliest colonisation and settlement and, as such, could contribute to questions of seafaring and coastal adaptation that cannot be addressed from the terrestrial data alone.

Nonetheless, we must be realistic. Research to date has only scratched the surface and hinted at the full extent and nature of the offshore record. This is clearly illustrated by the fact that the majority of evidence is intertidal rather than subtidal, and of the latter, no definitely in situ material other than the buried North Wall Quay fish traps has been found. We should also consider that Ireland's unique and complex pattern of glaciation, and of sea-level and palaeogeographic change, when coupled with present-day oceanographic conditions, produces a taphonomic situation that is not well suited to extensive archaeological preservation. Simply put, Irish submerged landscapes are not like those of the Baltic or the North Sea. The archaeological record is much shorter, concentrated within the Holocene, with perhaps brief windows into the Late Glacial. Extensive submerged landscapes are likely to be much rarer, given limited shelf exposure, glaciation and high-energy conditions. A situation where fragments of landscape or pockets of preservation characterise the Irish shelf is much more likely. Moreover, there is no guarantee that submerged sites will conclusively resolve the aforementioned questions on seafaring, coastal adaptation and human responses. With the best will in the world, we should accept that the idealised submerged site with fine-grained in situ preservation of seafaring and fishing activities may prove elusive.

On the other hand, by avoiding the offshore landscape, we also ignore a large chunk of Ireland's prehistory and, arguably, will make little headway in dealing with the above questions. We should also not underestimate the knowledge to be gained from looking at the environmental aspects of the submerged record. Improved knowledge of sea-level change and reconstruction of local- to regional-scale palaeogeography and environmental change can place the known archaeological record in a more accurate landscape context and also address some of the nuances surrounding seafaring and coastal adap- 
tation, particularly in relation to ecological affordances and palaeoceanographic conditions. Encouragingly, there are identifiable routes of investigation, based on the limited work done so far in Ireland, as well as approaches adopted from elsewhere. Particularly advantageous in the Irish context is the ready availability of vast quantities of seabed mapping data which have yet to be fully examined from an archaeological perspective. Ultimately though, the investigation of submerged landscapes is not something that can be done overnight. The realistic aspiration would be that, in the coming years, solid foundations can be put in place that will aid understanding and management and, in the long term, facilitate greater discovery of Ireland's submerged prehistory.

\subsection{Management of the Underwater Cultural Heritage}

The responsible authority for underwater cultural heritage including submerged landscapes lies with two organisations. In the Republic of Ireland, this is the Underwater Archaeology Unit of the National Monuments Service which is itself part of the Department of Culture, Heritage and the Gaeltacht (DCHG) (http://archaeology. ie/, accessed December 2018). In Northern Ireland, it is the Historic Environment Division of the Department for Communities (DfC) (https://www.communities-ni.gov.uk/articles/ dfc-marine-historic-environment, accessed December 2018).

Acknowledgements Peter Woodman sadly and unexpectedly passed away when this chapter was near completion. It would have been impossible to write without his unparalleled knowledge of Irish prehistory. Numerous other colleagues also deserve thanks for their assistance with research, fieldwork or simply putting up with longrunning discussions on submerged landscapes. These are Rory Quinn, Ruth Plets, Colin Breen, Wes Forsythe, Rory McNeary, Fraser Sturt, Justin Dix, Robin Edwards, Trevor Bell and Brian McNaught. Finally, thanks also to Graeme Warren and two anonymous reviewers for their insightful comments which improved the original draft.

\section{References}

Adams AL (1883) Report on the history of Irish fossil mammals. Proceedings of the Royal Irish Academy. Science 3:89-100

Atkins WS (1997) Wind and water. In: Barne JH, Robson CF, Kaznowska SS, Doody JP, Davidson NC, Buck AL (eds) Coasts and seas of the United Kingdom. Region 17 Northern Ireland. Joint Nature Conservation Committee, Peterborough, pp 28-32

Bailey G (2014) New developments in submerged prehistoric archaeology: an overview. In: Evans A, Flatman JC, Flemming NC (eds) Prehistoric archaeology on the continental shelf. A global review. Springer, Dordrecht, pp 291-300

Bailey G, Flemming N (2008) Archaeology of the continental shelf: marine resources, submerged landscapes and underwater archaeology. Quat Sci Rev 27:2153-2165

Bailey G, Sakellariou D (2012) SPLASHCOS: submerged prehistoric archaeology and landscapes of the continental shelf. Antiquity project gallery. http://antiquity. ac.uk/projgall/sakellariou334/

Ballantyne CK, Ó Cofaigh C (2017) The last Irish ice sheet: extent and chronology. In: Coxon P, McCarron S, Mitchell F (eds) Advances in Irish Quaternary studies. Atlantis Press, Paris, pp 101-149

Ballin T, Bjerck H (2016) Lost and found twice: discussion of an early post-glacial single-edged tanged point from Brodgar on Orkney, Scotland. J Lithic Stud 3:1-20

Bayliss A, Woodman PC (2009) A new Bayesian chronology for Mesolithic occupation at Mount Sandel, Northern Ireland. Proc Prehist Soc 75:101-123

Bell M (2007) Prehistoric coastal communities. The Mesolithic in Western Britain, CBA research report 149. Council for British Archaeology, York

Bell M, Warren G (2013) The Mesolithic. In: Ransley J, Sturt F, Dix J, Adams J, Blue L (eds) People and the sea: England's maritime and marine historic environment resource assessment and research agenda, CBA research report, vol 171. Council for British Archaeology, York, pp 30-49

Bell T, O'Sullivan A, Quinn R (2006) Discovering ancient landscapes under the sea. Archaeol Irel 20:12-17

Benjamin J, Bicket A, Anderson D, Hale A (2014) A multi-disciplinary approach to researching the intertidal and marine archaeology in the Outer Hebrides, Scotland. J I Coast Archaeol 9:400-424

Bjerck H (2017) Settlements and seafaring: reflections on the integration of boats and settlements among marine foragers in Early Mesolithic Norway and the Yámana of Tierra del Fuego. J I Coast Archaeol 12:276-299

Bradley SL, Milne GA, Shennan I, Edwards RJ (2011) An improved Glacio isostatic adjustment model for the British Isles. J Quat Sci 26:541-552

Brady N, Pollard E (2013) Archaeology and development in a maritime context, highlighting Drogheda and the 
Boyne estuary as a case study. In: Jameson JJ, Eogan J (eds) Training and practice for modern day archaeologists. Springer, New York, pp 237-269

Breen C (1993) The 'Pearl', Tran a Fearla, Allihies. Excavations Bulletin 1993: Summary accounts of archaeological excavations in Ireland. http://www. excavations.ie

Breen C, Forsythe W (2001) Management and protection of the maritime cultural resource in Ireland. Coast Manag 29:41-51

Brooks AJ, Edwards R (2006) The development of a sealevel database for Ireland. Irish J Earth Sci 24:13-27

Brooks AJ, Bradley SL, Edwards RJ, Milne GA, Horton BP, Shennan I (2008) Post-glacial relative sea-level observations from Ireland and their role in glacial rebound modelling. J Quat Sci 23:175-192

Brooks AJ, Bradley SL, Edwards RJ, Goodwyn N (2011) The paleogeography of Northwest Europe during the last 20,000 years. J Maps 2011:573-587

Bynoe R, Dix JK, Sturt F (2016) Of mammoths and other monsters: historic approaches to the submerged Palaeolithic. Antiquity 90:857-875

Campbell K (2003) Arklow Bank Wind Park. Offshore monitoring of dredging. Excavations Bulletin 2003: Summary accounts of archaeological excavations in Ireland. http://www.excavations.ie

Carter RWG (1982) Sea-level changes in Northern Ireland. Proc Geol Assoc 93:7-23

Charlesworth JK (1963) Historical geology of Ireland. Oliver and Boyd, Edinburgh

Clark CD, Hughes ALC, Greenwood SL, Jordan C, Sejrup HP (2012) Pattern and timing of retreat of the last British-Irish Ice Sheet. Quat Sci Rev 44:112-146

Coffey G, Praeger RL (1904/5) The Antrim Raised Beach: a contribution to the Neolithic history of the North of Ireland. Proc R Ir Acad Section C: Archaeol Celtic Stud 25:143-200

Cohen K, Westley K, Erkens G, Hijma MP, Weerts HJT (2017) The North Sea. In: Flemming NC, Harff J, Moura D, Burgess A, Bailey GN (eds) Submerged landscapes of the European continental shelf: Quaternary paleoenvironments. Wiley Blackwell, Chichester, pp 147-186

Common R (1933) Unusual Larne flint flake. Irish Nat J 4:139-140

Cooney G, Mandal S (1998) The Irish stone axe project: monograph 1. Wordwell, Dublin

Cooney G, Mandal S, O'Keefe E, Warren G (2012) Rathlin in early prehistory. In: Forsythe W, McConkey $\mathrm{R}$ (eds) Rathlin Island. An archaeological survey of a maritime landscape. TSO, Belfast, pp 46-85

Costa LJ, Sternke F, Woodman PC (2001) The analysis of a lithic assemblage from Eleven Ballyboes, County Donegal. Ulst J Archaeol 60:1-8

Coxon P, Mitchell F, von Engelbrechten S, Vaughan L (2017) Interglacial sequences. In: Coxon P, McCarron S, Mitchell F (eds) Advances in Irish Quaternary studies. Atlantis Press, Paris, pp 43-66
Davie S, Lordan C (2011) Examining changes in Irish fishing practices in response to the cold long-term plan. ICES J Mar Sci 68:1638-1646

Dorschel B, Wheeler AJ, Monteys X, Verbruggen K (2011) Atlas of the deep-water seabed, 1st edn. Springer, Dordrecht

Dowd M, Carden R (2016) First evidence of a Late Upper Palaeolithic human presence in Ireland. Quat Sci Rev 139:158-163

Dowling LA, Sejrup HP, Coxon P, Heijnis H (1998) Palynology, aminostratigraphy and U-series dating of marine Gortian interglacial sediments in Cork Harbour, southern Ireland. Quat Sci Rev 17:945-962

Driscoll K (2006) The early prehistory in the west of Ireland: investigations into the social archaeology of the Mesolithic, west of the Shannon, Ireland. Unpublished MLitt Thesis, National University of Ireland, Galway

Edwards RJ, Brooks AJ (2008) The island of Ireland: drowning the myth of an Irish land-bridge? In: Davenport J, Sleeman D, Woodman P (eds) Mind the pap: postglacial colonisation of Ireland. Special Supplement to the Irish Naturalists' Journal, vol 29, pp 19-34

Edwards RJ, Craven K (2017) Relative Sea-level change around the Irish coast. In: Coxon P, McCarron S, Mitchell F (eds) Advances in Irish Quaternary studies. Atlantis Press, Paris, pp 181-215

Edwards RJ, Brooks AJ, Shennan I, Milne G, Bradley S (2008) Reply: postglacial relative sea-level observations from Ireland and their role in glacial rebound modelling. J Quat Sci 23:821-825

Evans CDR (1995) Wind and water. In: Barne JH, Robson CF, Kaznowksa SS, Doody JP (eds) Coasts and seas of the United Kingdom. Region 12 Wales: Margam to Little Orme. Joint Nature Conservation Committee, Peterborough, pp 29-33

Evans W, Benetti S, Sachetti F, Jackson DWT, Dunlop P, Monteys X (2015) Bedforms on the northwest Irish shelf: indication of modern active sediment transport and over printing of paleo-glacial sedimentary deposits. J Maps 11:561-574

Fischer A (2011) Stone age on the continental shelf: an eroding resource. In: Benjamin J, Bonsall C, Pickard C, Fischer A (eds) Submerged prehistory. Oxbow, Oxford, pp 298-312

Fry M (2000) Coiti: Logboats from Northern Ireland. Greystone Press, Antrim

Gaffney V, Thomson K, Fitch S (2007) Mapping Doggerland: the Mesolithic landscapes of the southern North Sea. Archaeopress, Oxford

Garrow D, Sturt F (2011) Grey waters bright with Neolithic Argonauts? Maritime connections and the Mesolithic-Neolithic transition within the 'western seaways' of Britain, c. 5000-3500 BC. Antiquity 85:59-72

GEBCO (2014) The GEBCO_2014 Grid, version 20150318. www.gebco.net 
Gibson C (ed) (2011) Northern Ireland. State of the Seas Report. Agri-Food and Biosciences Institute and Northern Ireland Environment Agency, Belfast

Highley D, Hetherington L, Brown T, Harrison D, Jenkins $G$ (2007) The strategic importance of the marine aggregates industry to the UK. British Geological Survey Research Report OR/07/019

Kandrot S, Farrell E, Devoy R (2016) The morphological response of foredunes at a breached barrier system to winter 2013/14 storms on the south-west coast of Ireland. Earth Surf Process Landf 41:2123-2136

Kuchar J, Milne G, Hubbard A, Patton H, Bradley S, Shennan I, Edwards RJ (2012) Evaluation of a numerical model of the British-Irish ice sheet using relative sea-level data: implications for the interpretation of trimline observations. J Quat Sci 27:597-605

Lübke H, Schmölckem U, Tauber F (2011) Mesolithic hunter-fishers in a changing world: a case study of submerged sites on the Jäckelberg, Wismar Bay, northeastern Germany. In: Benjamin J, Bonsall C, Pickard C, Fischer A (eds) Submerged prehistory. Oxbow, Oxford, pp 21-37

Lynch M (2013) Prehistoric coastal midden sites in the west. In: Higgins J, Conneely A, Gibbons M (eds) Irish maritime heritage. Proceedings of the 3rd Galway international heritage conference. Crow's Rock Press, Galway, pp 1-10

Manning P (1970) Geology of Belfast and the Lagan valley. Her Majesty's Stationary Office, Belfast

McCabe AM (2008) Comment: postglacial relative sealevel observations from Ireland and their role in glacial rebound modelling. J Quat Sci 23:817-820

McCabe AM, Cooper JAG, Kelley JT (2007) Relative Sea-level changes from NE Ireland during the last glacial termination. J Geol Soc Lond 164:1059-1063

McErlean T, McConkey R, Forsythe W (2002) Strangford Lough: an archaeological survey of the maritime cultural landscape. Blackstaff Press, Belfast

McNaught B (1998) Early Mesolithic site discovered in Donegal. Donegal Annual 50:64-65

McQuade M (2008) Gone fishin. Archaeol Irel 22:8-11

McQuade M, O'Donnell L (2007) Late Mesolithic fish traps from the Liffey estuary, Dublin, Ireland. Antiquity 81:569-584

Milner N, Woodman PC (2007) Deconstructing the myths of Irish shell middens. In: Milner N, Craig O, Bailey $\mathrm{G}$ (eds) Shell middens in Atlantic Europe. Oxbow, Oxford, pp 101-110

Mitchell GF (1976) The Irish landscape. Collins, London Mithen S, Wicks K, Pirie A, Riede F, Lane C, Banerjea R, Cullen V, Gittens M, Pankhurst N (2015) A Lateglacial archaeological site in the far north-west of Europe at Rubha Port an t-Seilich, isle of Islay, western Scotland: Ahrensburgian-style artefacts, absolute dating and geoarchaeology. J Quat Sci 30:396-416

Mol D, Post K, Reumer J, van der Plicht J, de Vos J, van Geel B, van Reenen G, Pals JP, Glimmerveen J (2006) The Eurogeul - first report of the palaeontological, palynological and archaeological inves- tigations of this part of the North Sea. Quat Int 142-143:178-185

Monaghan NT (2017) Irish Quaternary vertebrates. In: Coxon P, McCarron S, Mitchell F (eds) Advances in Irish Quaternary studies. Atlantis Press, Paris, pp 255-291

Montgomery WI, Provan J, McCabe AM, Yalden DW (2014) Origin of British and Irish mammals: disparate post-glacial colonisation and species introductions. Quat Sci Rev 98:144-165

Morrison M, Stephens N, Jope M, Dance S, Anderson F, Round F, Godwin H, Willis E (1965) A submerged late-Quaternary deposit at Roddans Port on the northeast coast of Ireland. Philos Trans R Soc Lond, Ser B 249:221-255

Movius HL, Jessen K, McMillan N, Richardson F (1940/41) An early post-glacial archaeological site at Cushendun, County Antrim. Proc R Ir Acad Section C: Archaeol Celtic Stud Hist Linguist Lit 46:1-84

Movius HL, Jessen K, Benninghoff WS, McMillan N (1953/54) Curran Point, Larne, County Antrim: the type site of the Irish Mesolithic. Proc R Ir Acad Section C: Archaeol Celtic Stud Hist Linguist Lit 56:1-195

O'Connell M, Molloy K (2017) Mid- and late-Holocene environmental change in Western Ireland: new evidence from coastal peats and fossil timbers with particular reference to relative sea-level change. The Holocene 27(12):1825-1845

O'Mahony C, Sutton G, McMahon T, O'Cinneide M, Nixon E (2008) Policy report - issues and recommendations for the development and regulation of marine aggregate extraction in the Irish Sea. Marine Environment and Health Series 32

O'Raw J (2003) The Saldahna disaster in the maritime cultural landscape of Lough Swilly. Unpublished MSc Thesis, Ulster University, Coleraine

O'Riordain SP (1953/54) Lough Gur excavations: Neolithic and Bronze age houses on Knockadoon. Proc R Ir Acad Section C: Archaeol Celtic Stud Hist Linguist Lit 56:297-459

O'Sullivan A (2001) Foragers, farmers and fishers in a coastal landscape: an intertidal archaeological survey of the Shannon estuary. Royal Irish Academy, Dublin

Patterson WH (1892) On a newly discovered site for worked flints in the County of Down. J R Soc Antiqu Ireland 2:154-155

Pettitt P, White M (2012) The British Palaeolithic. Human societies at the edge of the Pleistocene world. Routledge, Abingdon

Plets RMK, Callard SL, Cooper JAG, Long AJ, Quinn RJ, Belkap DF, Edwards RJ, Jackson DWT, Kelley JT, Long D, Milne GA, Monteys X (2015) Late Quaternary evolution and sea-level history of a glaciated marine embayment, Bantry Bay, SW Ireland. Mar Geol 369:251-272

Power D (1994) Archaeological inventory of County Cork, vol 2 (East and South Cork). Stationary Office, Dublin 
Praeger RL (1891) A report on the estuarine clays of the North-East of Ireland. Proc R Ir Acad 2:212-289

Praeger RL (1892) The Irish Post-Glacial estuarine deposits. Ir Nat 1:138-141

Quinn R, Lafferty B, Westley K, Plets R (2012) The natural environment. In: Forsythe W, McConkey R (eds) Rathlin Island. An archaeological survey of a maritime landscape. TSO, Belfast, pp 20-44

Richards MP, Jacobi R, Cook J, Pettitt PB, Stringer $\mathrm{CB}$ (2005) Isotope evidence for the intensive use of marine foods by Late Upper Palaeolithic humans. J Hum Evol 49:390-394

Roe HM, Swindles GT (2008) Post-glacial evolution of the Lower Dun Valley, Co. Antrim: a re-examination of the Movius (1940) sections at Cushendun. In: Whitehouse NJ, Roe HM, McCarron S, Knight J (eds) North of Ireland field guide. Quaternary Research Association, London, pp 117-127

Savage RJG (1966) Irish Pleistocene mammals. Irish Nat J $15: 117-130$

Schmitt L (2015) The continental connection: a coastal excursion in time, geography and culture. Nor Archaeol Rev 48:21-26

Schmitt L, Svedhage K (2015) Chronological aspects of the Hensbacka - a group of hunter-gatherers/fishers on the west coast of Sweden during the Pleistocene/ Holocene transition: an example of early coastal colonization. Dan J Archaeol 4:1-7

Shee Twohig ES (1995) An inter-tidal passage tomb at 'the Lag', Ringarogy Island, Co. Cork. Archaeol Irel 9:7-9

Simpson D (2008) Greyabbey Bay, Strangford Lough: marine, non-marine and terrestrial micro- and macrofossils. In: Whitehouse NJ, Roe HM, McCarron S, Knight J (eds) North of Ireland field guide. Quaternary Research Association, London, pp 155-167

Singh G (1963) Pollen-analysis of a deposit at Roddans Port, Co. Down, N. Ireland, bearing reindeer antler fragments. Grana Palynol 4:466-474

Stewart SA (1911) The latest fluctuations of the sea-level on our own coasts. Ir Nat 20:17-27

Stillman CJ (1968) The post glacial change in sea level in South-Western Ireland: new evidence from freshwater deposits on the floor of Bantry Bay. Sci Proc R Dublin Soc A3:125-127

Sturt F, Garrow D, Bradley S (2013) New models of North West European Holocene palaeogeography and inundation. J Archaeol Sci 40:3963-3976

The Crown Estate (2014) Protocol for archaeological discoveries: offshore renewables projects. Wessex Archaeology, Salisbury, on behalf of The Crown Estate

Tizzard L, Baggaley P, Firth A (2011) Seabed prehistory: investigating palaeolandsurfaces with Palaeolithic remains from the southern North Sea. In: Benjamin J, Bonsall C, Pickard C, Fischer A (eds) Submerged prehistory. Oxbow, Oxford, pp 65-74

Tolan-Smith C (2009) Mesolithic Britain. In: Bailey G, Spikins P (eds) Mesolithic Europe. Cambridge University Press, Cambridge, pp 132-157
Van Kolfschoten T, Laban C (1995) Pleistocene terrestrial mammal faunas from the North Sea area. Med Rijks Geol Dienst 52:135-151

Warren G (2015a) Britain and Ireland inside Mesolithic Europe. In: Anderson-Whymark H, Garrow D, Sturt F (eds) Continental connections: exploring crosschannel relationships from the Mesolithic to the Iron age. Oxbow, Oxford, pp 43-58

Warren G (2015b) 'Mere food gatherers they, parasites upon nature...': food and drink in the Mesolithic of Ireland. Proc R Ir Acad 115C:1-26

Warren G (2017) The human colonisation of Ireland in Northwest European context. In: Coxon P, McCarron S, Mitchell F (eds) Advances in Irish Quaternary studies. Atlantis Press, Paris, pp 293-316

Warren G, Davis S, McClatchie M, Sands R (2014) The potential role of humans in structuring the wooded landscapes of Mesolithic Ireland: a review of data and discussion of approaches. Veg Hist Archaeobotany 23:629-646

Wessex Archaeology (2013) Fishing industry protocol for archaeological discoveries final report. Wessex Archaeology, Salisbury

Westley K (2015) Submerged archaeological landscape investigation, Eleven Ballyboes, Republic of Ireland. Int J Naut Archaeol 44:243-257

Westley K, Edwards R (2017) Irish Sea and Atlantic Margin. In: Flemming NC, Harff J, Moura D, Burgess A, Bailey GN (eds) Submerged landscapes of the European continental shelf: Quaternary paleoenvironments. Wiley Blackwell, Chichester, pp 241-280

Westley K, Quinn R, Forsythe W, Plets R, Bell T, Benetti S, McGrath F, Robinson R (2011a) Mapping submerged landscapes using multibeam bathymetric data: a case study from the north coast of Ireland. Int J Naut Archaeol 40:99-112

Westley K, Bell T, Plets R, Quinn R (2011b) Investigating submerged archaeological landscapes — a research strategy illustrated with case studies from Ireland and Newfoundland, Canada. In: Benjamin J, Bonsall C, Pickard C, Fischer A (eds) Submerged prehistory. Oxbow, Oxford, pp 129-144

Westley K, Plets R, Quinn R (2014) Holocene palaeogeographic reconstructions of the Ramore Head area, Northern Ireland, using geophysical and geotechnical data: palaeo-landscape mapping and archaeological implications. Geoarchaeol Int J 29:411-430

Whitehouse NJ, Watson J, Turney C (2008) Roddans Port Late Glacial site. In: Whitehouse NJ, Roe HM, McCarron S, Knight J (eds) North of Ireland field guide. Quaternary Research Association, London, pp 168-173

Whitehouse NJ, Schulting R, McClatchie M, Barratt P, McLaughlin TR, Bogaard A, Colledge S, Marchant R, Gaffrey J, Bunting MJ (2014) Neolithic agriculture on the European western frontier: the boom and bust of early farming in Ireland. J Archaeol Sci 51:181-205

Williams DM, Doyle E (2014) Dates from drowned midHolocene landscapes off the Central Western Irish seaboard. Irish J Earth Sci 32:23-27 
Wilson P, Westley K, Plets R, Dempster M (2011) Radiocarbon dates from the inter-tidal peat bed at Portrush, County Antrim. Ir Geogr 44:323-329

Woodman PC (1977) A narrow-blade Mesolithic site at Glynn, County Antrim. Ulst J Archaeol 40:12-20

Woodman PC (1978) The Mesolithic in Ireland. Archaeopress, Oxford

Woodman PC (2012) Making yourself at home on an island: the first 1000 years (+?) of the Irish Mesolithic. Proc Prehist Soc 78:1-34
Woodman PC (2015) Ireland's first settlers. Time and the Mesolithic. Oxbow, Oxford

Woodman PC, McCarthy M, Monaghan N (1997) The Irish Quaternary Fauna project. Quat Sci Rev 16:129-159

Woodman PC, Anderson E, Finlay N (1999) Excavations at Ferriter's Cove 1983-1995. Last foragers/first farmers in the Dingle peninsula. Wordwell, Dublin

Open Access This chapter is licensed under the terms of the Creative Commons Attribution 4.0 International License (http://creativecommons.org/licenses/by/4.0/), which permits use, sharing, adaptation, distribution and reproduction in any medium or format, as long as you give appropriate credit to the original author(s) and the source, provide a link to the Creative Commons licence and indicate if changes were made.

The images or other third party material in this chapter are included in the chapter's Creative Commons licence, unless indicated otherwise in a credit line to the material. If material is not included in the chapter's Creative Commons licence and your intended use is not permitted by statutory regulation or exceeds the permitted use, you will need to obtain permission directly from the copyright holder. 